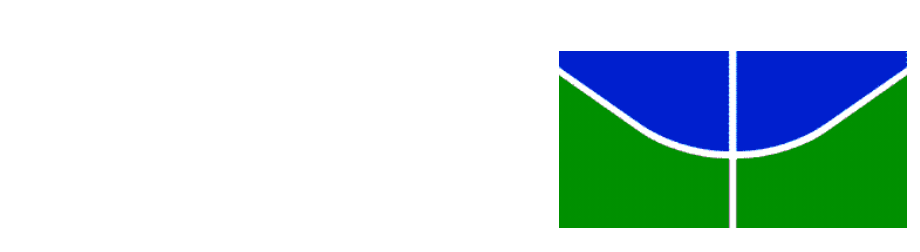

UNIVERSIDADE DE BRASÍLIA

FACULDADE DE AGRONOMIA E MEDICINA VETERINÁRIA

RECONSTITUIÇÃO DE GRÃOS DE MILHO SOBRE O CONSUMO, DIGESTIBILIDADE APARENTE DOS NUTRIENTES E PARÂMETROS RUMINAIS DE OVINOS

EDUARDO GUIMARÃES BRANDÃO

DISSERTAÇÃO DE MESTRADO EM CIÊNCIAS ANIMAIS

BRASÍLIA/DF

FEVEREIRO DE 2016 


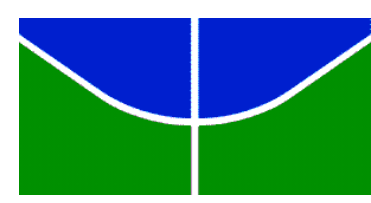 \\ UNIVERSIDADE DE BRASÍLIA \\ FACULDADE DE AGRONOMIA E MEDICINA VETERINÁRIA}

RECONSTITUIÇÃO DE GRÃOS DE MILHO SOBRE O CONSUMO, DIGESTIBILIDADE APARENTE DOS NUTRIENTES E PARÂMETROS RUMINAIS DE OVINOS

EDUARDO GUIMARÃES BRANDÃO

ORIENTADOR: CLAYTON QUIRINO MENDES

DISSERTAÇÃO DE MESTRADO EM CIÊNCIAS ANIMAIS

PUBLICAÇÃ̃:152/2016

BRASÍLIA/DF

FEVEREIRO DE 2016 
UNIVERSIDADE DE BRASÍLIA

FACULDADE DE AGRONOMIA E MEDICINA VETERINÁRIA

RECONSTITUIÇÃO DE GRÃOS DE MILHO SOBRE O CONSUMO, DIGESTIBILIDADE APARENTE DOS NUTRIENTES E PARÂMETROS RUMINAIS DE OVINOS

EDUARDO GUIMARÃES BRANDÃO

DISSERTAÇÃO DE MESTRADO SUBMETIDA AO PROGRAMA DE PÓSGRADUACAÇÃO EM CIÊNCIAS ANIMAIS DA FACULDADE DE AGRONOMIA E MEDICINA VETERINÁRIA DA UNIVERSIDADE DE BRASÍLIA, COMO PARTE DOS REQUISITOS PARA OBTENÇÃO DE GRAU DE MESTRE EM CIÊNCIAS ANIMAIS.

APROVADA POR:

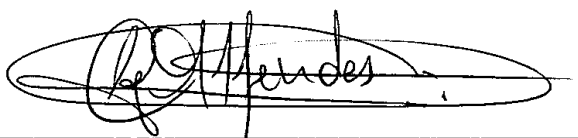

CLAYTON QUIRINO MENDES

Universidade de Brasília - UnB (Orientador)

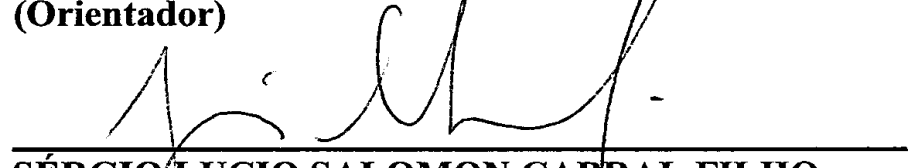

SÉRGIOLUCIO SALOMON CABRAL FILHO

Universiłdade de Brasília - UnB

(Examinador Interno)

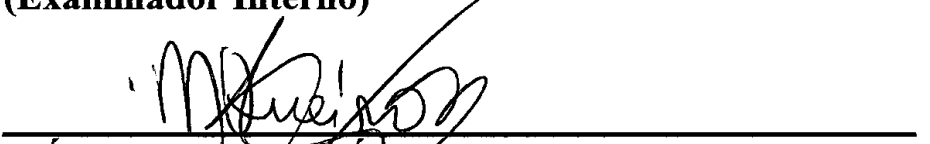

MÁRIO ADRIATO ÁZHA QUEIROZ

Universidade Eeteral do Vale do São Francisco - Univasf

(Examinador Externo)

BRASÍLIA/DF, 23 de fevereiro de 2016 


\section{REFERÊNCIA BIBLIOGRÁFICA E CATALOGAÇÃO}

BRANDÃO, E.G. Reconstituição de grãos de milho sobre o consumo, digestibilidade aparente dos nutrientes e parâmetros ruminais de ovinos. Brasília: Faculdade de Agronomia e Medicina Veterinária, Universidade de Brasília, 2016, 59 p. Dissertação de Mestrado.

Documento formal, autorizando reprodução desta dissertação de mestrado para empréstimo ou comercialização, exclusivamente para fins acadêmicos, foi passado pelo autor à Universidade de Brasília e achase arquivado na Secretaria do Programa. O autor e seu orientador reservam para si os outros direitos autorais, de publicação. Nenhuma parte desta dissertação de mestrado pode ser reproduzida sem a autorização por escrito do autor ou do seu orientador. Citações são estimuladas, desde que citada à fonte.

Ficha catalográfica elaborada automaticamente, com os dados fornecidos pelo autor

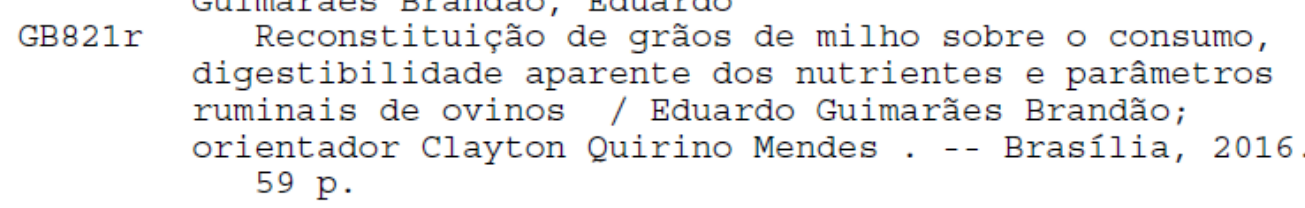




\section{DEDICO}

Aos meus pais

Aos meus pais Jairo Gomes Brandão e Ielda de Fátima Guimarães Brandão

À minha irmã

Fernanda Guimarães Brandão

À minha namorada

Savana Lorrane Pereira Alves

Ao meu orientador

Prof. Dr. Clayton Quirino Mendes

E aos professores

Cássio José da Silva e Sergio Lucio Salomon Cabral Filho 


\section{AGRADECIMENTOS}

Agradeço inicialmente aos meus pais que sempre me persuadiram a seguir meus sonhos. Minha mãe em sua persistência para que eu terminasse o estágio e meu pai por seus planos mirabolantes em nossa chácara.

A minha irmã por todo apoio e paciência em meus anos de estudos e farras, e principalmente por ser minha companhia, pois irmãos são pessoas que não escolhemos, mas mesmo assim se tornam melhores amigos eternos.

A minha namorada, que mesmo fazendo parte a pouco tempo da minha vida, me impulsiona para momentos incríveis.

Ao meu orientador professor Clayton Quirino Mendes por todo empenho em forjar o caráter de seus alunos. Ao professor e grande amigo Sérgio Lúcio, que há tempos me orienta e aconselha sobre as coisas da vida, por sua paciência e inestimável amizade. Ao professor e amigo Cássio José, por sempre estar disposto a compartilhar seus conhecimentos e pela ajuda essencial na construção do meu mestrado.

Aos meus amigos Wolney, Hortênsia, Yann, Jéssica, Yuri, Paula, Thais, Arthur, Natália, Elídio, Jaiane, Teresa, Carlos, Luana, Jânio e Giovanna, pela amizade, paciência e marcante ajuda no experimento, sem vocês eu não teria conseguido terminar o meu experimento. Aos grandes companheiros de trabalho e convivência do Centro de Manejo de Ovinos (CMO) Antônio, Gilson, Seu Zé, Dona Célia, Cláudio e Romilson agradeço por sempre me ajudarem e me tratarem com respeito e amizade.

Aos meus amigos e colegas do mestrado João Paulo, Rômulo e Renata, pela ajuda no experimento, nas infinitas análises do laboratório e nos momentos de descanso, pois apenas mestrandos se entendem durante a condução de experimentos. 
A professa Aline e as colegas de mestrado pelo apoio nas análises no Laboratório de Nutrição Animal (LNA).

Ao Laboratório de Microscopia Eletrônica e Virologia no Instituto de Biologia da Universidade de Brasília pelo auxilio nas imagens.

A CAPES pela disponibilidade da bolsa de estudo.

E também a todos meus amigos que aguentaram o meu estresse e compartilharam os momentos de felicidades em nossos churrascos.

"A felicidade só é verdadeira quando compartilhada"

Chris McCandless. 


\section{INDICE}

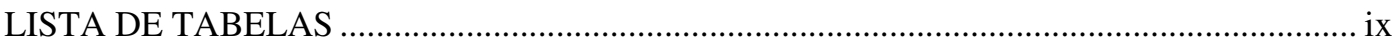

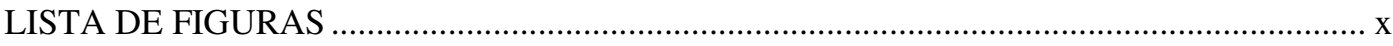

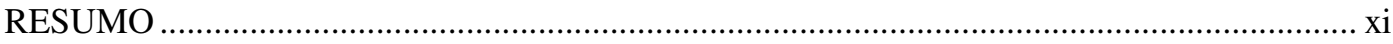

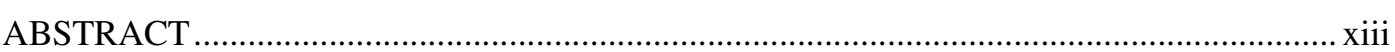

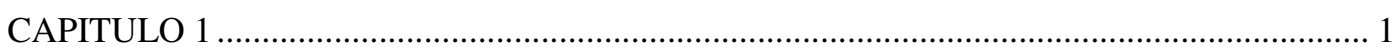

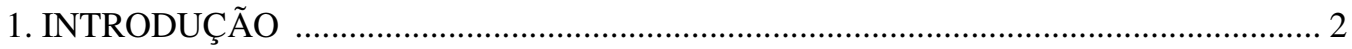

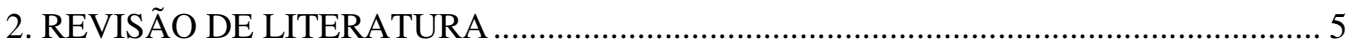

2.1. Estrutura do grão do milho ……………….............................................................. 5

2.2. Processamento do grão ............................................................................................. 7

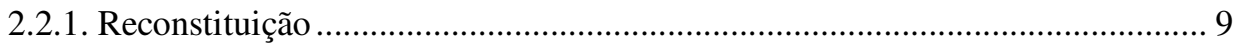

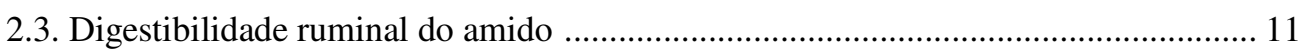

2.4. Dieta de alto grão para ruminantes .......................................................................... 13

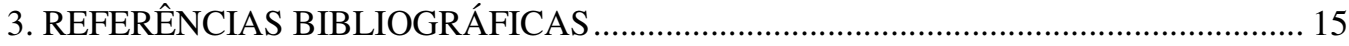

CAPITULO 2 - CONSUMO E DIGESTIBILIDADE APARENTE DA MATÉRIA SECA E NUTRIENTES, PH, N-NH3, GLICOSE SANGUÍNEA E MICROSCOPIA ELETRONICA DE

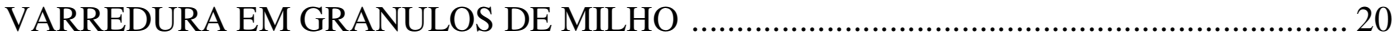

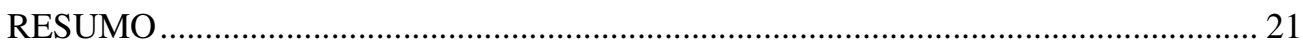

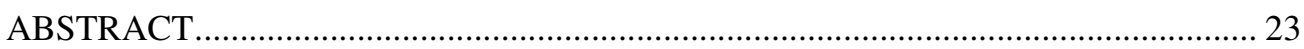

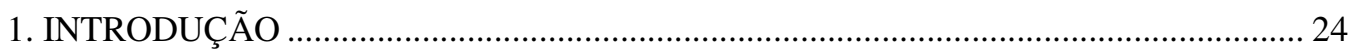

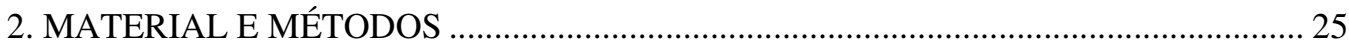

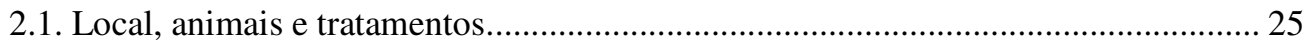

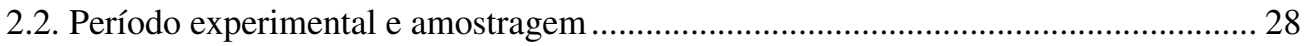

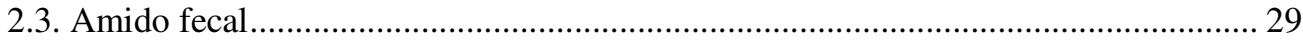

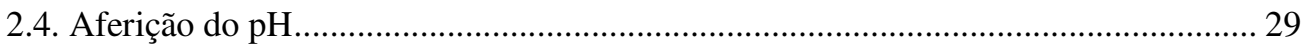

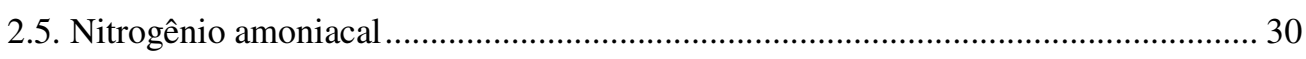

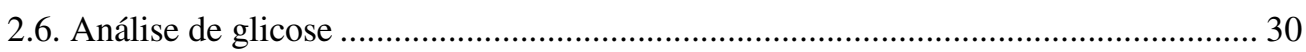

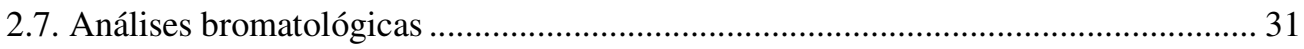

2.8. Microscopia eletrônica.......................................................................................... 32

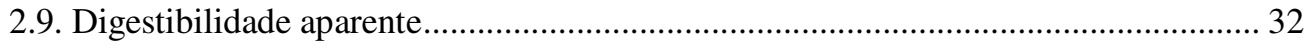

2.10. Análises estatísticas ................................................................................................... 32

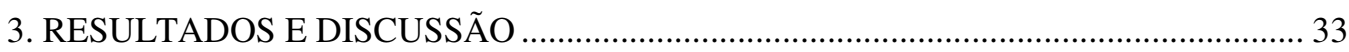

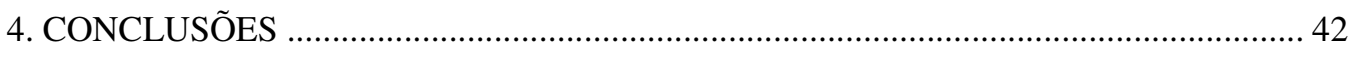

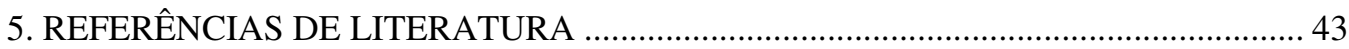




\section{LISTA DE TABELAS}

Tabela 1 Proporção dos ingredientes e composição nutricional das dietas experimentais ... . 27

Tabela 2 Composição bromatológica do milho, do farelo de soja e do feno (g/kg de MS).. . 28

Tabela 3 Consumo e digestibilidade aparente da matéria seca e dos nutrientes da dieta. ...... 34

Tabela 4 pH ruminal e concentração de nitrogênio amoniacal . .36

Tabela 5 Concentração de glicose no plasma sanguíneo .38 


\section{LISTA DE FIGURAS}

Figura 1 Estrutura do grão de milho 3

Figura 2 Tipos de milho e as relativas proporções do endosperma farináceo e vítreo............ 4

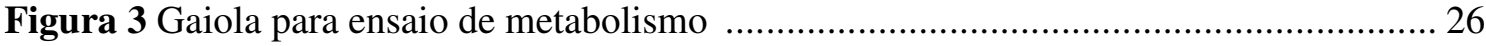

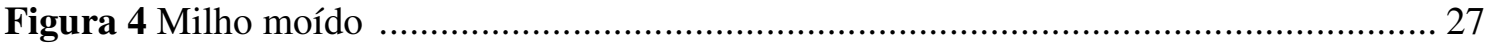

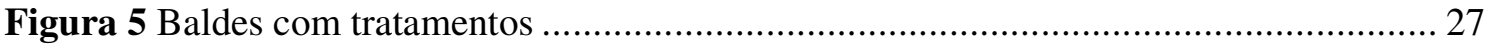

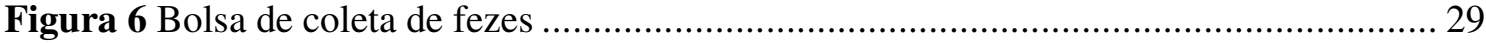

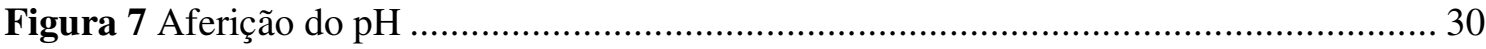

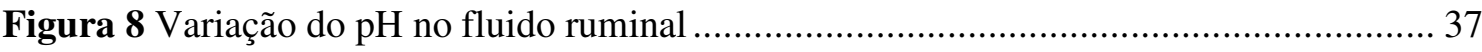

Figura 9 Variação da concentração de $\mathrm{N}^{-\mathrm{NH}_{3}}$ do fluído ruminal ............................................ 38

Figura 10 Fotomicrografia eletrônica do milho reconstituído ........................................... 40 


\title{
RESUMO \\ RECONSTITUIÇÃO DE GRÃOS DE MILHO SOBRE O CONSUMO, DIGESTIBILIDADE APARENTE DOS NUTRIENTES E PARÂMETROS RUMINAIS DE OVINOS
}

\author{
Eduardo Guimarães Brandão ${ }^{1}$, Clayton Quirino Mendes ${ }^{1}$ \\ ${ }^{1}$ Faculdade de Agronomia e Medicina Veterinária da Universidade de Brasília, DF.
}

Objetivou-se avaliar os efeitos da reconstituição da umidade com solução alcalina $(\mathrm{NaOH})$ e salina $(\mathrm{NaCl})$ associada à moagem grosseira dos grãos de milho sobre o consumo, a digestibilidade aparente dos nutrientes e os parâmetros ruminais de ovinos. Foram utilizados 12 ovinos machos, mestiços, castrados e fistulados no rúmen. Os animais foram distribuídos em delineamento inteiramente casualizado, mantidos em gaiolas para ensaio de metabolismo e distribuídos em quatro tratamentos: controle - milho moído sem reconstituição; $\mathrm{NaOH}$ milho moído e reconstituído com solução alcalina a 0,5\%; $50 \mathrm{NaOH}: 50 \mathrm{NaCl}$ - milho moído e reconstituído com $50 \%$ de solução alcalina a $0,5 \%+50 \%$ de solução salina a $10 \%$; e $\mathrm{NaCl}$ milho moído e reconstituído com solução salina a 10\%. As dietas experimentais foram compostas por feno de Tifton-85 e concentrado na proporção 40:60. Foram avaliados o consumo e a digestibilidade aparente dos nutrientes, o pH ruminal, a concentração de nitrogênio amoniacal e o teor de glicose no plasma sanguíneo e os grânulos de amido a partir da microscopia eletrônica de varredura. $\mathrm{O}$ tratamento com $\mathrm{NaCl}$ apresentou maior consumo $(\mathrm{P}<0,05)$ para extrato etéreo e amido, mas não apresentou variações em suas digestibilidades. Não houve efeito dos tratamentos sobre o pH ruminal e a concentração de glicose plasmática. Houve maior concentração de nitrogênio amoniacal no tratamento com $\mathrm{NaCl}$. Microscopicamente as estruturas dos grânulos de amido não foram afetadas pelos tipos de reconstituição, apenas se observou um espaçamento e irregularidade entre os grânulos em relação ao tratamento Controle. A reconstituição de grãos de milho com as concentrações das 
soluções utilizadas no presente trabalho não apresentou vantagens qualitativas em relação ao milho não reconstituído.

Palavras-chave: cloreto de sódio, grânulo de amido, hidróxido de sódio, milho reconstituído, $\mathrm{pH}$ ruminal. 


\title{
ABSTRACT \\ CORN GRAIN RECONSTITUTION ON INTAKE AND DIGESTIBILITY OF NUTRIENTS AND RUMINAL PARAMETERS OF SHEEP
}

\author{
Eduardo Guimarães Brandão ${ }^{1}$, Clayton Quirino Mendes ${ }^{1}$ \\ ${ }^{1}$ School of Agronomy and Veterinary Medicine - University of Brasilia, DF.
}

The objective of this trial was to evaluate the effects of moisture replenishment with alkaline solution $(\mathrm{NaOH})$ and salt $(\mathrm{NaCl})$ associated with the coarse grinding of corn kernels on intake, apparent nutrient digestibility and ruminal characteristics of sheep. Twelve male sheep crossbred, castrated and rumen canuleted were used. Animals were distributed in a completely randomized design, housed in metabolic cages and test for four treatments: control - ground corn without reconstruction; $\mathrm{NaOH}$ - milled corn and reconstituted with alkaline solution at 0,5\%; $50 \mathrm{NaOH}: \mathrm{NaCl} 50$ - milled corn and reconstituted with $50 \%$ bleach solution $+50 \%$ brine; $\mathrm{NaCl}$ - milled corn and reconstituted with saline solution at $10 \%$. The experimental diets were composed by $40 \%$ of Tifton- 85 hay and $60 \%$ of concentrated. Were evaluated intake and apparent digestibility of nutrients, ruminal $\mathrm{pH}$, ammonia nitrogen and blood plasma glucose concentration. Also the starch granules from the scanning electron microscopy. Treatment with $\mathrm{NaCl}$ showed higher $(\mathrm{P}<0,05)$ for ether extract and starch intake, but no differences in their digestibility. There was no treatments effect on ruminal $\mathrm{pH}$ and plasma glucose concentration. A higher concentration of ammonia nitrogen was verified in the treatments containing $\mathrm{NaCl}$. Microscopically the structures of starch granules were not affected by the types of reconstruction, only there was irregularity and spacing among beads compared to the control treatment. Reconstitution of corn grain with of the solutions used in this study did not show qualitative advantages.

Keywords: reconstituted corn grain, sodium chloride, sodium hydroxide, starch granule, ruminal $\mathrm{pH}$. 
CAPITULO 1 


\section{INTRODUÇÃO}

A busca pela maximização do lucro na cadeia produtiva do leite e da carne, a estacionalidade da produção de forragens em grande parte do território nacional e a escolha por animais com altos níveis de exigências tem levado a adoção cada vez maior por sistemas de confinamento com dietas com altos níveis de inclusão de grãos na alimentação de ruminantes. Nesse caso, a nutrição é o fator de maior importância, pois o custo com alimentação tem grande impacto sobre o custo total da atividade, podendo ser responsabilizado, em média, por até $70 \%$ no custo de produção (LOPES et al. 2011).

Segundo a CONAB (2015), a safra brasileira de grãos 2014/2015 alcançou 209,5 milhões de toneladas, com mais um recorde sobre os números passados. O aumento é de 8,2\%, ou 15,9 milhões de toneladas, sobre da produção de 2013/14, de 193,62 milhões de toneladas. A soja e o milho safrinha foram os principais responsáveis pela safra recorde de grãos no período. A soja apresentou incremento de 11,8\%, chegando a 96,2 milhões de toneladas. O milho $2^{\text {a }}$ safra registrou 54,5 milhões de toneladas, avanço de 12,6\% sobre o ciclo anterior.

Entre os cereais utilizados nas dietas de ruminantes, o milho (Zea mays) é o mais usado, considerado rico em energia e pobre em proteína (TEIXEIRA, 1998). A maior parte do milho comercial produzido nacionalmente é do tipo duro (Zea mays ssp. Indentura), enquanto, nos países de clima temperado, a predominância é do tipo dentado (Zea mays ssp. Indentata).

O milho dentado é caracterizado pela presença de endosperma vítreo nas laterais do grão e o centro do grão, que se estende à coroa e apresenta endosperma farináceo. Ao desidratar, a parte central do grão se endurece para formar uma distinta conformação dentada. O milho duro tem endosperma vítreo, com pequena proporção de endosperma farináceo e apresenta núcleo arredondado e não dentado (NUSSIO et al. 2001; PAES, 2006). 
No endosperma vítreo, os grânulos de amido são revestidos por uma densa matriz proteica altamente resistente a hidrólise enzimática, já no endosperma farináceo a matriz proteica é delgada e mais susceptível a hidrólise enzimática (PAES, 2006). Os diferentes tipos de endosperma afetam diretamente a escolha do processamento a ser utilizado nos grãos e das possíveis implicações da utilização destes alimentos para ruminantes (SILVA, 2012).

Em vista da necessidade de aperfeiçoar a utilização dos grãos, vários autores apresentaram dados sobre métodos de processamentos de grãos visando à alimentação de ruminantes (OWENS et al. 1986; THEURER, 1986; HUNTINGTON, 1997; ZINN et al. 2002). Hale (1973) relacionou 18 diferentes métodos de processamentos e concluiu que o processamento apropriado deve resultar em utilização mais eficiente do amido nos grãos de cereais.

A escolha do processamento pode implicar significativamente no valor nutritivo dos grãos de cereais para bovinos de corte (NRC, 1996). O fator mais determinante é a exposição do amido dos grãos e a maior degradação enzimática, sendo que a intensidade do processamento escolhido pode afetar no tempo de fermentação. A forma mais rotineira de fornecimento dos grãos é na forma moída, por se tratar de um processamento simples e prático, diminuindo o tamanho das partículas, o que provavelmente não é o mais eficaz por acarretar uma rápida fermentação ruminal do amido e grandes variações no pH do rúmen (ALCALDE, 1997).

Dessa forma, além da escolha dos ingredientes na formulação das dietas e o teor de nutrientes neles presentes, deve se atentar ao tipo de processamento a ser utilizado, pois este irá afetar desde a ingestão até o aproveitamento pelo animal. Os efeitos e benefícios dos diferentes tipos de processamento dos grãos têm como fundamento básico a quebra das barreiras que impedem o acesso da microbiota ruminal e as enzimas aos componentes nutricionais, sendo que o efeito do calor e da umidade apresentam maiores resultados (THEURER, 1986). Porém, métodos de processamento de grãos de milho como tratamento a vapor, floculação ou laminação tornam o processo mais caro.

Silva (2012) cita que o incremento do fator reconstituição associado a uma moagem grosseira dos grãos de milho pode facilitar o acesso das enzimas microbianas aos grânulos de amido. Considerando a necessidade de métodos simples e de fácil execução em nível de campo, a reconstituição da umidade do grão do milho moído grosseiramente surge como uma alternativa para o melhor aproveitamento do amido do milho pelos ruminantes. 
O objetivo desse trabalho foi avaliar os efeitos da reconstituição da umidade dos grãos de milho com solução alcalina $(\mathrm{NaOH})$ ou salina $(\mathrm{NaCl})$ sobre o consumo, a digestibilidade aparente dos nutrientes e os parâmetros ruminais de ovinos. 


\section{REVISÃO DE LITERATURA}

\subsection{Estrutura do grão do milho}

O grão de milho é formado por quatro principais estruturas físicas: pericarpo (película de proteção externa), endosperma, gérmen (embrião), e ponta (Figura 1), as quais diferem na composição química e na organização dentro do grão.

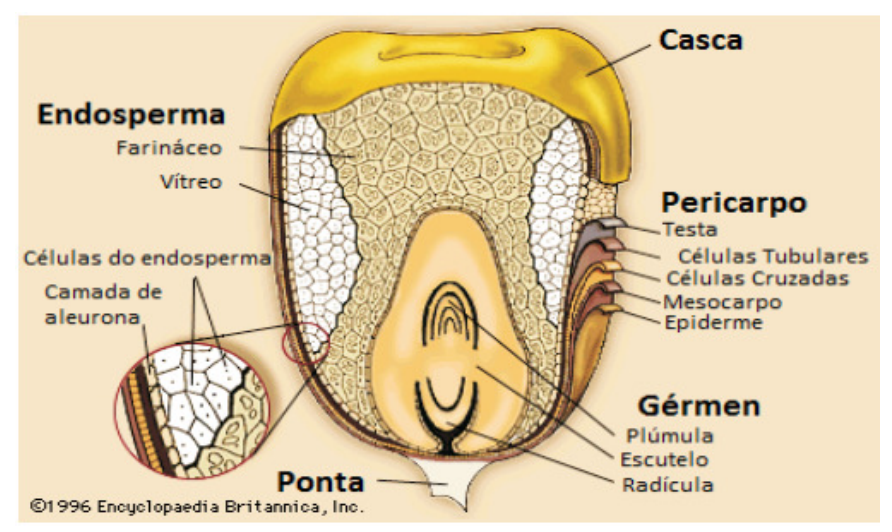

Figura 1: Estrutura do grão de milho.

Fonte: http://docplayer.com.br/1008596

O pericarpo, em média, representa apenas 5\% da estrutura do grão, sendo responsável pela proteção das estruturas subsequentes das variações de umidade do ambiente e pragas. Subdivido em camadas constituídas de polissacarídeos do tipo hemicelulose (67\%), celulose $(23 \%)$ e lignina $(0,1 \%)$, sendo responsável por até $54 \%$ da fibra do grão de milho. No endosperma, maior constituinte do grão ( $83 \%$ do peso seco), estão presentes as proteínas de reserva (8\%) do tipo prolaminas (zeínas) e o amido (88\%). Essas proteínas formam os corpos proteicos que compõem a matriz, as quais envolvem os grânulos de amido dentro das células no endosperma. O gérmen representa $11 \%$ do grão de milho e concentra quase a totalidade 
(83\%) dos lipídeos (óleo e vitamina E) e dos minerais (78\%) do grão, além de conter quantidades importantes de proteínas (26\%) e açúcares (70\%). Essa fração é o único tecido vivo do grão e onde se encontram as proteínas do tipo albuminas, globulinas e glutelinas, as quais diferem quanto à composição e organização molecular daquelas presentes no endosperma. A ponta é a menor estrutura, 2\% do grão, e é responsável pela conexão do grão ao sabugo, sendo a única área do grão não coberta pelo pericarpo. Sendo sua composição essencialmente de matéria lignocelulósica (PAES, 2006).

Com base na distribuição dos grânulos de amido e da matriz proteica, o endosperma é classificado em dois tipos: farináceo e vítreo. No primeiro, os grânulos de amido são arredondados e estão dispersos, não havendo matriz proteica circundando essas estruturas. Apresentando pouca estrutura celular e alta densidade dos grânulos de amido. Por outro lado, no endosperma vítreo, a matriz proteica é densa, com corpos proteicos estruturados, que circundam os grânulos de amido de forma poligonal, impedindo desta forma espaços vagos entre as estruturas. A matriz proteica é impermeável à água e a enzimas hidrolíticas (KOTARSKI et al. 1992; PAES, 2006).

De acordo com as características do grão, existem cincos classes ou tipos de milho: dentado, duro ou cristalino, farináceo, pipoca e doce. Sendo a diferença referente à forma e o tamanho dos grãos, de acordo com a estrutura do endosperma e o tamanho do gérmen (Figura 2). Tal classificação procede aos grãos secos e aderidos ao sabugo, sendo que em uma mesma espiga com aparência de dois tipos a classificação será de acordo com a maior prevalência dos grãos em questão (PAES, 2006).

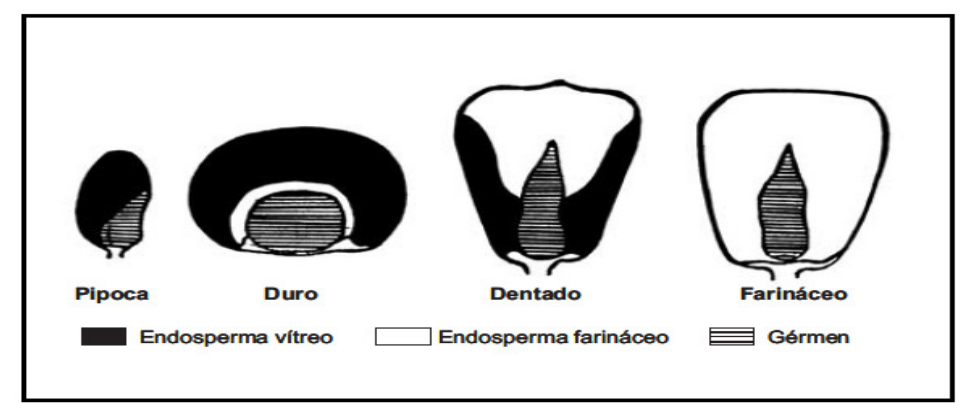

Figura 2: Tipos de milho e as relativas proporções do endosperma farináceo e vítreo.

Fonte: Adaptado de Paes (2006)

O principal componente energético dos grãos de cereais é o amido, representando $60-80 \%$ da composição dos grãos. É a reserva de energia mais significativa em plantas superiores, estando presente também nas raízes e tubérculos de leguminosas. O amido 
é um polissacarídeo não estrutural de elevada massa molecular composto de dois polímeros: amilose e amilopectina. Sendo sua estrutura constituída por camadas concêntricas alternadas semicristalinas rígidas e em camadas macias amorfas (THEURER, 1986; KOTARSKI et al. 1992).

A amilose é uma molécula linear de unidades de $\alpha$-D-glicopiranose (1500 unidades de glicose) ligadas em $\alpha-(1,4)$, e representa em média 20 a 30\% do amido, podendo variar de 0 a $80 \%$, com poucas ligações $\alpha-(1,6)$. A amilopectina é composta por uma cadeia linear de $\alpha$-D-glicopiranose (17 a 25 unidades de glicose), com ligações $\alpha$-(1,4) e ramificações fortes com ligações $\alpha-(1,6)$ e representa de 70 a $80 \%$ do amido dos cereais, como o milho e o sorgo. Fisicamente, o amido se constitui de grânulos, nos quais a amilose e amilopectina estão ligadas por pontes de hidrogênio (FRENCH, 1973; NOCEK e TAMMINGA, 1991; KOTARSKI; WANISKA; THURN, 1992).

\subsection{Processamento do grão}

A partir de processamentos adequados a utilização de grãos passa a ser maior aproveitada pelos ruminantes. Entretanto, os benefícios e custos que tal processamento impõe dependem da escolha do método efetuado e que tipo de grão será utilizado. Desta forma, o termo "grãos processados" se aplica aos métodos extensivos de preparação de grãos na confecção das dietas, enquanto o termo "não processado" se designa a grãos integrais (THEURER, 1986).

Os diferentes métodos de processamento visam ampliar a disponibilidade do amido e, desta forma, fornecer mais energia para o animal, amplificando a resposta ao manejo e desempenho animal. Isso ocorre pela ruptura de barreiras primárias como o pericarpo e redução da influência da matriz proteica em torno dos grânulos de amido, que aumenta a área de exposição e possibilita a fixação das bactérias aos grânulos, aumentando a fermentação ruminal e a maior produção de ácidos graxos de cadeia curta (AGCC) (HALE, 1973; OWENS et al. 1986; THEURER, 1986).

Existem, pelo menos, 18 diferentes métodos de processamentos de grãos, como mecânico e o térmico, e de acordo com a classificação: a seco ou úmido. O tratamento mecânico envolve o descascamento, prensagem, moagem, ensilagem e laminação. Já o tratamento térmico envolve o calor seco: tostagem, micronização, estalação e peletização; e o calor úmido: cozimento sob pressão, dilatação, explosão e floculação. Porém, nem todos são viáveis economicamente e/ou tecnologicamente ao sistema que o produtor necessita (HALE, 1973; THEURER, 1986; VARGAS JÚNIOR et al. 2008). 
O processamento causa o rompimento da matriz proteica presente no endosperma do grão, o que permite as enzimas microbianas ou intestinais acesso facilitado aos grânulos de amido. Hale (1973), em estudos histológicos de grãos processados através do calor e pressão, demonstrou a desorganização da matriz proteica ao redor dos grânulos de amido.

A moagem é o processo que se refere à redução do tamanho de grãos ou matérias primas em partículas menores através do impacto ou atrito, sendo capaz de influenciar na digestibilidade do amido e da proteína. É o método de preparação de grãos mais utilizado, por ser de simples realização e de preço acessível, sendo realizado principalmente por moinhos tipo martelo que são capazes de controlar o grau de finura e a distribuição granulométrica das partículas trituradas através de peneiras (ENSMINGER et al. 1990). O tamanho do moinho, sua capacidade e velocidade, tipo de grão, conteúdo de umidade do grão escolhido e a espessura da peneira irão influenciar diretamente o produto final.

A laminação é o processo em que o grão passa por rolos e é comprimido em partículas achatadas. Podendo ser realizada sem adição de água (laminação a seco) ou após submeter o grão ao vapor (laminação a vapor). Na laminação a seco ocorre a passagem do grão, entre uma série de cilindros de aço. O tamanho da partícula varia de muito fina até muito grossa e é influenciado pela pressão dos rolos e do espaço entre eles, conteúdo de umidade do grão, e taxa de fluxo do grão (ENSMINGER et al. 1990). Já na laminação a vapor o grão é exposto ao vapor pro aproximadamente 15 minutos e é pressionado por rolos de diversos tamanhos, sendo que a densidade das partículas varia entre 438 a 540 gramas por litro, causando acréscimo de $6 \%$ na umidade do grão laminado (ENSMINGER et al. 1990; THEURER et al. 1999). Simas (1997) relata que tal processo pode aumentar a palatabilidade e a digestibilidade do grão.

A micronização consiste na aplicação de calor através de queimadores infravermelhos. O tempo de exposição à fonte de calor varia dependendo do tipo de grão, sendo utilizado durante certo tempo que varia entre 25 segundos e 2 minutos. Devido a esse tempo de exposição, são alcançados temperaturas de $140-180^{\circ} \mathrm{C}$ (TAIT et al 1988). Os raios infravermelhos penetram nos grãos e produzem uma vibração de frequência elevada nas moléculas do seu interior, originando um aquecimento interno muito rápido e uma elevação da pressão de vapor de água; os grãos se tornam gelatinosos, se incham e finalmente estalam (30-40\% dos grãos), após essa etapa os grãos são passados entre cilindros aplastadores, os quais dão forma estável de flocos, e na continuação são refrigerados para reduzir sua temperatura (BENEDÍ, 1989). 
O cozimento é um processamento pela aplicação de calor úmido. Observa-se que este processamento, em muitos trabalhos de pesquisa, diminui a digestibilidade da proteína e aumenta levemente a digestibilidade do amido e geralmente não melhora o desempenho animal.

A floculação é o processo em que a aplicação do vapor é mais bem monitorada, do que na laminação com aplicação de vapor, fazendo com que a umidade do grão aumente até níveis próximos a $18 \%$. Dessa maneira são necessários aproximadamente 12 minutos de vapor para os grãos de milho e de no mínimo o dobro do tempo para os grãos de sorgo. A espessura do grão floculado é menor $(0,9$ a $1,1 \mathrm{~mm})$ do que o grão laminado (1,5 a 2,4 mm) devido aos grãos passarem por um segundo par de rolos ajustados para comprimirem ainda mais os grãos. A temperatura do grão eleva a aproximadamente $100{ }^{\circ} \mathrm{C}$ no momento em que entram no primeiro rolo de prensagem, o que causa a gelatinização (hidratação e ruptura do complexo molecular) dos grânulos de amido (HALE e THEURER, 1972; ENSMINGER et al. 1990). A floculação dos grãos causa melhoria na degradação ruminal e na disponibilidade do amido em relação à laminação a seco ou vapor (ENSMINGER et al. 1990). Conforme estes autores ocorre aumento da palatabilidade e consumo de matéria seca com o uso do milho floculado.

Na reconstituição, é feita uma adição de água ao grão seco, com o intuito de elevar o conteúdo de umidade a 25-30\%, o que ocorre num tempo médio de 24 a 48 horas, o grão reconstituído envolve processamento que se assemelha a um encharcamento, o qual resulta em um produto final similar ao grão com alta umidade. $\mathrm{O}$ tipo de grão, umidade alcançada, temperatura ambiente e tempo de duração do processo vão afetar os benefícios desse processamento (SILVA, 2012). Segundo este autor deve-se levar em consideração as alterações no valor nutritivo do grão processado e também os custos envolvidos em aquisição de maquinários, operação e manutenção para a escolha do processamento a se utilizar.

\subsubsection{Reconstituição}

O processo de reconstituição consiste em elevar o teor de umidade até um ponto desejado através da adição de água aos grãos de milho. Indo contra ao gasto de energia na secagem do grão, tal processo pode maximizar a digestibilidade do amido através do maior acesso da microbiota ruminal ao endosperma do grão do milho (SILVA, 2012).

A dureza do endosperma está relacionada com a composição química, basicamente a composição proteica (albuminas, proteínas solúveis em água; globulinas que podem ser extraídas com solução salina; com álcool e água, as prolaminas). Os grânulos de 
amido dentro das células estão envoltos por uma matriz proteica, onde a densidade da matriz varia de acordo com a localização da célula no grão. No endosperma farináceo a matriz é esparsa e fragmentada, já no endosperma vítreo é densa e bem desenvolvida (PAES, 2006; SILVA, 2012).

Devido a sua constituição no endosperma, na porção farinácea os grânulos de amido estão mais acessíveis ao ataque enzimático. Porém, tal interação com a proteína pode reduzir a susceptibilidade do amido à hidrólise enzimática, reduzindo a digestibilidade deste carboidrato, além da presença do pericarpo (SILVA, 2012). O pericarpo representa, em média, 5\% do grão, sendo a estrutura que protege as outras estruturas do grão da elevada umidade do ambiente, insetos e microrganismos (PAES, 2006).

De acordo com Jobim (1996), os grãos de milho, mesmo quando triturados ou parcialmente quebrados, são protegidos pelo pericarpo, o qual é muito resistente à degradação microbiana e digestão enzimática no intestino delgado devido à proteção parcial pelo pericarpo e a matriz proteica que envolve os grânulos de amido dificultando o acesso de enzimas microbianas. Silva (2012) cita que o incremento do fator reconstituição associado a uma moagem grosseira dos grãos de milho pode facilitar o acesso das enzimas microbianas aos grânulos de amido.

A moagem quebra a estrutura do endosperma, e o reumedecimento causa diferentes graus de gelatinização (rompimento dos grãos de amido), expondo os grânulos de amido à digestão. A gelatinização ocorre quando os grânulos de amido absorvem água e incham, liberando amilose e amilopectina, o que aumenta a hidrólise enzimática e resulta em melhor aproveitamento pela microbiota ruminal. Quando a gelatinização ocorre no endosperma farináceo, o amido é digerido mais rápido do que quando a gelatinização ocorre no endosperma vítreo ou periférico (HALE, 1973; KOTARSKI et al. 1992; SIMAS, 1997; ÍTAVO et al. 2006).

O endosperma dos cereais, em especial a região periférica, é cercado por uma parede celular rica em compostos $\beta$-glucanos que prejudica a atividade microbiana; e também a matriz proteica que envolve os grânulos de amido dificulta a atividade das amilases, visto que deve ocorrer uma proteólise simultânea, para que as bactérias possam utilizar o amido. Desta forma, quando o pericarpo é separado no caso da moagem grosseira, as características da matriz proteica e do endosperma do grão irão determinar a taxa de adesão e fermentação do amido pelas bactérias ruminais (KOTARSKI et al. 1992, McALLISTER et al. 1993). 


\subsection{Digestibilidade ruminal do amido}

$\mathrm{O}$ amido, quando ingerido pelo ruminante, é submetido primeiramente à fermentação microbiana no rúmen, sendo estas as responsáveis por grande fração da digestão do amido. Em sua predominância numérica e diversidade metabólica as bactérias ruminais são: Streptococcus bovis, Bacteroides amylophilus, Bacteroides ruminocola, Ruminobacter amylophilus, Eubacterium ruminantium, Ruminococcus bromii, Prevotella ruminicola, Butyrivibrio fibrisolvens, Succinimonas amylolytica, Selenomona lactylitica, Selenomona Ruminantium e Lactobacillus sp (CHURCH, 1979; COTTA, 1988; KOTARSKI et al. 1992). Produzindo células microbianas e ácidos graxos de cadeia curta. Posteriormente, o amido sofre digestão enzimática, no intestino delgado, produzindo glicose (HALE, 1973; WALDO, 1973; THEURER, 1986).

De acordo com Zhang et al. (2006) o endosperma do grão de milho, devido a sua constituição (vítreo ou farináceo), cria uma barreira contra as enzimas amilolíticas isoladas na digestão do amido. Todavia, quando uma população microbiana mista no rúmen atua sobre esses grânulos de amido isolados, o efeito das barreias é menos expressivo (McALLISTER et al. 1993; FONDEVILA e DEHORITY, 2001). Tal processo demonstra a efetividade, diversidade e um efeito de inter-relação da microbiota ruminal na produção de amilases, observado com frequência sobre a os grânulos de amido (SILVA, 2012).

Geralmente, $90 \%$ do amido do trigo, da aveia e da cevada são rapidamente degradados no rúmen, pois o endosperma e a matriz proteica são facilmente penetrados pelos micro-organismos, iniciando-se a partir de um ponto central de fixação microbiana na superfície do grânulo. Já no milho, forma se um túnel da superfície para o interior dos grânulos de amido onde a digestão se dá de dentro para fora, consequentemente, o interior dos grânulos muitas vezes fica vazio, com apenas a camada exterior resultante (McALLISTER e CHENG, 1996). Devido a uma taxa mais lenta de digestão, cerca de $40 \%$ do amido do milho pode escapar da fermentação ruminal. A matriz proteica, que envolve os grânulos de amido do milho, é resistente à adesão e penetração pelos micro-organismos. Porém, se o grão do milho sofrer algum tipo de processamento que envolva temperatura e umidade pode ter melhor degradabilidade no rúmen, assim como os outros amidos de cereais (ØRSKOV, 1986; THEURER, 1986; MCALLISTER et al. 1993).

Dentro da população microbiana, os fungos e protozoários também desempenham grande papel na degradação do amido, sendo os protozoários responsáveis por até $50 \%$ da digestão do amido no rúmen (JOUANY e USHIDA, 1999). Protozoários são responsáveis por engolfarem grandes quantidades de grânulos de amido, causando 
significativo impacto na digestão de grãos de cereais. Desta forma, possuem grande capacidade na modulação do pH (USHIDA et al. 1991), devido ao resultado da sua capacidade de engolfar grânulos de amido e predação de bactérias amilolíticas (NAGARAJA et al. 1992). Coleman (1986) demonstrou que os grânulos de amido podem levar até 36 h para serem completamente metabolizados pelos protozoários.

Os fungos podem passar despercebidos por serem vistos apenas como responsáveis pela digestão da parede celular das forragens, entretanto, observa se um aumento representativo da sua função na biomassa ruminal com acréscimo de grãos na dieta (FAICHNEY et al. 1997). De fato, os fungos não possuem função expressiva na digestão ruminal do amido, porém muitas espécies apresentam atividade amilolítica e sua principal ação característica de penetrar através das barreiras primárias, formando assim canais no endosperma vítreo e possibilitando a colonização secundária por bactérias (McALLISTER e CHENG, 1996).

As bactérias amilolíticas secretam amilases, por não conseguirem ingerir partículas de amido, ou utilizam de outros mecanismos associados à parede celular (como proteínas ligantes) para hidrolisar o amido e transportá-lo para o interior da célula (KOTARSKI et al. 1992). Desta forma, tais bactérias têm preferência por colonizarem grânulos de amido que já foram parcialmente afetados por um processamento prévio ou decorrente da digestão de outros microrganismos ruminais (SILVA, 2012).

As amilases têm a capacidade de quebrar as ligações glicosídicas $\alpha(1,4)$ e $\alpha$ $(1,6)$ das moléculas de amilose e amilopectina, liberando vários fragmentos. Entretanto, nem todas as bactérias possuem todas as enzimas que promovem a degradação total do amido até glicose, sendo necessária, então, a existência de endo e exo amilases do tipo $\alpha(1,4)$ e $\alpha(1,6)$. Desta forma a sintonia entre as diversas espécies de bactérias é fundamental para a fermentação do amido (HUNTINGTON, 1997).

Segundo Philippeau et al. (2000), no grão de milho, a digestibilidade do amido é inversamente proporcional com os níveis de proteína, sendo as relações entre vitreosidade do endosperma e digestão do amido observados com frequência (KOTARSKI et al. 1992).

Após a colonização pela microbiota, se dá início a hidrolise enzimática do amido, a digestão do amido se dá por uma gama de enzimas que fragmentam os grânulos de amido em cadeias menores de polissacarídeo, os quais são rapidamente hidrolisados no liquido ruminal (CONE, 1991).

Quanto maior for à inclusão de fontes de amido na dieta, ocorrera maior degrabilidade deste no rúmen, porém, em relação à digestão no trato total, a proporção de amido digerido no rúmen irá diminuir (RUSSELL et al. 1981; HUNTINGTON, 1997). O 
restante do amido não digerido no rúmen segue para o intestino, de acordo com os padrões de motilidade ruminal, da taxa global de passagem e do tamanho das partículas (SILVA, 2012).

Com a chegada de altos níveis de amido no rúmen, ocorre pico de atividade, tanto de bactérias amilolíticas, como celulolíticas, gerando produção acelerada de AGCC entre $30 \mathrm{~m}$ a 4 h pós alimentação (VAN SOEST, 1994). De preferência, a produção de acetato é decorrente da fermentação de carboidratos de forragens (OWENS, 1988), enquanto o amido gera prevalecente o propionato (KOZLOSKI, 2002). A rápida produção de AGCC pode ultrapassar a taxa de absorção do rúmen ou o efeito tampão da saliva produzida, causando a queda do pH ruminal. Abaixo de $\mathrm{pH}$ 6,0, algumas espécies de bactérias iniciam a via da produção de lactato. Com o declínio do $\mathrm{pH}(5,5-5,0)$, se cria uma inversão na produção de lactato e de AGCC (SLYTER, 1976; OWENS, 1998), pois o lactato é um ácido mais forte que os AGCC (pKa de 3,8 vs 4,8-4,9), provocando ainda mais a queda do pH (VAN SOEST, 1994). Efeito que se não revertido pode levar a um caso de acidose ruminal, causando alterações nas características físico-químicas do líquido ruminal, atonia ruminal, seguida de acidose sistêmica, desidratação, prostração, coma e, frequentemente, morte (MARUTA; ORTOLANI, 2002).

Com isso, para se obter produção de AGCC e sua absorção adequadas, deve-se respeitar os limites de fermentação ruminal através de um compilado de técnicas e manejo, como a relação volumoso:concentrado, nível de processamento no grãos, adaptação dos animais a dieta e o tipo de grão a ser utilizado na formulação de alimentos para ruminantes (SILVA, 2012).

\subsection{Dieta de alto grão para ruminantes}

Com o advento do uso de dietas de alto grão, a necessidade por alterações no manejo alimentar visando à estabilidade ruminal, como o uso de aditivos, fibras ou processamentos dos grãos, se torna de grande importância (CARDOSO, 2012).

De acordo com Reynolds (2006), em artigo de revisão, a produção média de sólidos do leite de vacas vem aumentando linearmente nos últimos 50 anos, o que faz com que seja cada vez mais desafiante atender as exigências de animais de alto potencial genético, sem afetar a saúde e a reprodução. A suplementação com amido, através de dietas com altos níveis de concentrado, se torna uma opção muito utilizada para aumentar a densidade da dieta na tentativa de atender a demanda de carbono e glicose exigida por vacas de alta produção.

Dentro do processo de produção e terminação de bovinos de corte, a energia entra como um dos nutrientes de suma importância. Nesse plano, o milho é um dos alimentos 
mais tradicionais utilizados para atender as demandas energéticas dos animais (HUNTINGTON, 1997; OWENS et al. 1997).

A idade final dos animais confinados tende a diminuir com o aumento da inclusão de concentrado na dieta, o que influencia todo o planejamento do confinamento. Missio et al. (2009) demonstrou que com acréscimo de concentrado na dieta houve melhora da conversão alimentar devido à maior densidade energética, aumentando do ganho diário e afetando positivamente o desempenho dos animais.

De acordo com Susin (2001), a dieta de custo mínimo em confinamentos é aquela com alta proporção de concentrado. Perez (2002) cita que a terminação de cordeiros em confinamento com alimentos de elevado valor nutritivo e processamentos eficazes se tornam prioridade para que a manutenção dos animais com estas dietas atenda às exigências nutricionais para obtenção do desempenho desejado, de forma que a relação custo/benefício seja lucrativa para o produtor e possa proporcionar carcaças com qualidade e aceitação no mercado.

Segundo Medeiros et al. (2009), a utilização do confinamento é uma alternativa essencial para impulsionar a produção de carne ovina, pois permite maximizar o uso destes animais em pequenas áreas. Dietas com alto teor de grãos também podem apresentar ser viáveis para ovinos, pois podem demonstrar os mesmos benefícios e cuidados que se utiliza para bovinos. 


\section{REFERÊNCIAS BIBLIOGRÁFICAS}

ALCALDE, C.R. Avaliação da granulométrica ou hidratação do milho através da digestibilidade aparente, degradabilidade ruminal e desempenho de bovinos. Jaboticabal, SP: UNESP, 1997, 111p. Tese (Doutorado em Zootecnia) - Universidade Estadual Paulista, Faculdade de Ciências Agrárias e Veterinárias, Campus de Jaboticabal, 1997.

BENEDÍ, J. M.H. Manual de nutrición y alimentación del ganado. Ministerio de agricultura, pesca y alimentación. Madrid. 3 ed. Servicio de Extensión Agrária, p 495. 1989.

CARDOSO, E.O. Dieta de alto grão para bovinos confinados: viabilidade econômica e qualidade de carne. 2012. 66p. Dissertação (Mestrado em Zootecnia) Campus de Itapetinga - Universidade Estadual do Sudoeste da Bahia, Itapetinga, 2012.

CHURCH, D.C. 1979. Digestive physiology and nutrition of ruminants. Digestive Physiology. 2 ed., Corvallis, OR. 1979.

COLEMAN, G.S. The metabolism of rumen ciliate protozoa. FEMS Microbiol. Letters. v.39, p321-344. 1986.

CONAB - Companhia nacional de Abastecimento. Acompanhamento da Safra Brasileira de grãos - Safra 2014/2015. v.2, $\mathrm{n} \quad 12,2015$. Disponível em: http://www.agricultura.gov.br/politica-agricola/noticias/2015/09/safra-brasileira20142015-fecha-com-recorde-de-209-milhoes-de-toneladas-de-graos. Acessado em: $15 / 12 / 2015$

CONE, J.W. Degradation of starch in feed concentrates by enzymes, rúmen fluid and rumen enzymes. Journal of Science Food Agricultural. v.54, p.23-34. 1991.

COTTA, M.A. Amylolytic activity of selected species of ruminal bacteria. Applied and Environmental Microbiology. v.54, p.772-776. 1988.

ENSMINGER, M.E; OLDFIELD, J.E; HEINEMANN, W.W. Feed processing. In: Feeds \& nutrition. 2 ed. The ensminger publishing company, c.14, p.527-552. 1990. 
FAICHNEY, G.J.; PONCET, C.; LASSALAS, B.; JOUANY, J.P.; MILLET, L.; DORE, J.; BROWNLEE, A.G. Effect of concentrates in a hay diet on the contribution of anaerobic fungi, protozoa and bacteria to nitrogen in rumen and duodenal digesta of sheep. Animal Feed Science and Technology. v.64, p.193-213. 1997.

FONDEVILA, M.; DEHORITY B.A.. In vitro growth and starch digestion by Entodinium exiguum as influenced by the presence or absence of live bacteria. Journal of Animal Science. p.79. 2001.

FRENCH, D. Chemical and physical properties of starch. Journal Animal Science, v.37, p.1048-1061, 1973.

HALE, W.H.; THEURER, B.C. Feed preparation and processing. In: Digestive physiology and nutrition of ruminants, v.3, Pratical nutrition. 1972.

HALE, W.H. Influence of processing on the utilization of grains (starch) by ruminants. Journal of Animal Science, p.37, 1973.

HUNTINGTON, G.B. Starch utilization by ruminants: from basics to the bunk. Journal of Animal Science, v.75, p.852-867, 1997.

ÍTAVO, C.C.B.F.; MORAIS, M.G.; ÍTAVO, L.C.V.; SOUZA, A.R.D.L.; OSHIRO, M.M.; BIBERGA, F.A.; COSTA, C.; JOBIM, C.C.; LEMPP, B. Efeitos de diferentes fontes de concentrado sobre o consumo e a produção de cordeiros na fase de terminação. Revista Brasileira de Zootecnia, v.35, n.1, p.139-146, 2006.

JOBIM, C.C. Avaliação das características microbiológicas, químicas e digestibilidade das silagens de grãos úmidos e de espiga de milho. 1996. 98p Tese (Doutorado em Zootecnia) - Faculdade de Ciências Agrárias e Veterinária, Universidade Estadual Paulista, Jaboticabal, 1996.

JOUANY, J.P.; USHIDA, K. The role of protozoa in feed digestion - review. Asian Australasian Journal of Animal Science. v.12, p113-128. 1999.

KOTARSKI, S.F.; WANISHA, R.D.; THURN, K.K. Starch hydrolysis by ruminal microflora. Journal of Nutrition, v.122, p.178-190, 1992.

KOZLOSKI, V.G. Bioquímica microbiana ruminal. In: Bioquímica dos ruminantes. 1 ed. Santa Maria: UFMS, cap. 1, p.140, 2002.

LOPES, L.S.; LADEIRA, M.M.; MACHADO NETO, O.R.; SILVEIRA, A.R.M.C.; REIS; R.P.; CAMPOS, F.R. Viabilidade econômica da terminação de novilhos nelore e Red norte em confinamento na região de Lavras - MG. Ciência e Agrotecnologia, v.35, n.4, p.774-780, 2011.

MARUTA, C.A.; ORTOLANI, E.L. Suscetibilidade de bovinos das raças Jersey e Gir à acidose láctica ruminal: Acidose metabólica e metabolização do lactato-L. Ciência Rural. v.32, p.61-65, 2002. 
McALLISTER, T.A.; PHILLIPPE, R.C.; RODE, L.M.; CHENG, K.J. Effect of the protein matrix on the digestion of cereal grains by ruminal microorganisms. Journal of Animal Science, v.71, p.205-212, 1993.

McALLISTER, T.A.; CHENG, K.J. Microbial strategies in the ruminal digestion of cereal grains. Animal Feed Science and Technology. v.62, p.29-36, 1996.

MEDEIROS, G.R.; CARVALHO, F.F.R.; BATISTA, A.M.V.; JUNIOR, W.M.D.; SANTOS, G.R.A.; ANDRADE, D.K.B. Efeito dos níveis de concentrado sobre as características de carcaça de ovinos Morada Nova em confinamento. Revista Brasileira de Zootecnia, v.38, n.4, p.718-727, 2009.

MISSIO, R.L.; BRONDANI, I.L.; FREITAS, L.S.; SACHET, R.H.; SILVA, J.H.S.; RESTLE, J. Desempenho e avaliação econômica da terminação de tourinhos em confinamento alimentados com diferentes níveis de concentrado na dieta. Revista Brasileira de Zootecnia, v.38, n.7, p.1309-1316, 2009.

NAGARAJA, T. G.; TOWNE, G.; BEHARKA, A. A. Moderation of ruminal fermentation by ciliated protozoa in cattle fed a high-grain diet. Applied and Environmental Microbiology. v.58, p2410-2414, 1992.

NATIONAL RESEARCH COUNCIL. Nutrient requeriment of Beef Cattle. Washington, D.C., 1996,158 p.

NOCEK, J. E.; TAMMINGA, S. Site of digestion of starch in the gastrointestinal tract of dairy cows and its effect on milk yield and composition. Jounal of Dairy Science, Savoy, v. 74, p. 3598-3629, 1991.

NUSSIO, L.G.; CAMPOS, F.P.; DIAS, F.N. Importância da qualidade da porção vegetativa no valor alimentício da silagem de milho. In: SIMPÓSIO SOBRE PRODUÇÃO E UTILIZAÇÃO DE FORRAGENS CONSERVADAS, 2001, Maringá. Anais...Maringá: UEM/CCA/DZO, p.127-145, 2001.

ØRSKOV, E.R. Starch digestion and utilization in ruminants. Journal of Animal Science, v.63, p.1624-1633, 1986.

OWENS, F.N.; ZINN, R.A.; KIM, Y.K. Limits to starch digestion in the ruminant small intestine. Journal of Animal Science, Savoy, v. 63, p. 1634-1648, 1986.

OWENS, F.N. Ruminal fermentation. In: The ruminant animal Digestive physiology and nutrition. 1 ed. D. C. Church, ed. Waveland Press, Inc., Prospect Heights, Illinois. p.564, 1988.

OWENS, F.N.; SECRIST, D.S.; HILL, W.J.; GILL, D R. The effect of grain source and grain processing on performance of feedlot cattle: a review. Journal of Animal Science. v.75, p.868-879, 1997.

PAES, M.C.D. Aspectos Físicos, Químicos e Tecnológicos do Grão de Milho. Circular Técnica, Embrapa Milho e Sorgo. 2006.

PEREZ, J.R.O.; BRESSAN, M.C.; BRAGAGNOLO, N.; PRADO, O.V.; LEMOS, A.L.S.C.; BONAGURIO, S. Efeito do peso ao abate de cordeiros Santa Inês e Bergamácia sobre o 
perfil de ácidos graxos, colesterol e propriedades químicas. Ciência e Tecnologia de Alimentos, v.22, n.1, p.11-18, 2002.

REYNOLDS, C.K. Production and metabolic effects of site of starch digestion in dairy cattle. Animal Feed Science and Technology, v.130, p.78-94, 2006.

RUSSELL, J. B., COTTA, M. A.; DOMBROWSKI, D.B.. Rumen bacterial competition in continuous culture: Streptococcus bovis versus Megasphaera elsdenii. Applied and Environmental Microbiology. v.41, p1394-1399, 1981.

SILVA, C.J. Processamento de grãos de milho para uso na alimentação de vacas leiteiras. 2012. 99p. Tese (Doutorado em Zootecnia) - Universidade Federal de Viçosa, Viçosa, 2012.

SILVA, C.J.; Da COSTA, B.F.D.; LEITE, G.G.; MENDES, C.Q. Avaliação das características estruturais e do valor nutricional do grão de milho reconstituídos com diferentes soluções. Revista Eletrônica de Pesquisa Animal, v.1, n.1, p.27-28, 2013.

SIMAS, J.M. Processamento de grãos para rações de vacas leiteiras. In: Anais... Simpósio Sobre Produção Animal, 9, Piracicaba, FEALQ, p.7-32. 1997.

SUSIN, I. Confinamento de cordeiros. In: REUNIÃO ANUAL DASOCIEDADE BRASILEIRA DE ZOOTECNIA, 38, 2001, Piracicaba. Palestras... Piracicaba: Sociedade Brasileira de Zootecnia, p.454-459, 2001.

TAIT, R.M.; BEAMES, R.M.; ORSKOV, E.R. Processing and preservation of cereals and protein concentrates. In: World Animal Science, v. 4, 1988.

THEURER, C.B. Grain processing effects on starch utilization by ruminants. Journal of Animal Science. v.63, p.1649-62, 1986.

THEURER, C.B.; HUBER, J.T.; DELGADO-ELORDUY. A. Invited review: Summary of steam-flaking corn or sorghum grain for lactating dairy cows. Jounal of Dairy Science. v.82, p.1950-1959, 1999.

TEIXEIRA, A.S. Alimentos e alimentação dos animais. Lavras, UFLA - FAEPE, p.402, 1998.

USHIDA, K.; JOUANY, J.P.; DEMEYER, D.I. Effects of presence or absence of rumen protozoa on the efficiency of utilisation of concentrate and fibrous feeds. In Physiological Aspects of Digestion and Metabolism in Ruminants. T. Tsuda, Y. Sasaki and R. Kawashima (Eds). Academic Press, Tokyo. p 625-654, 1991.

VAN SOEST, P.J. Nutritional ecology of the ruminants. 2.ed. Ithaca:Cornell University, 1994, $476 \mathrm{p}$.

VARGAS JÚNIOR, F.M.; SANCHEZ, L.M.B.; WECHSLER, F.S.; BIANCHINI, W.; OLIVEIRA, M.V.M. Influência do processamento do grão de milho na digestibilidade de rações e no desempenho de bezerros. Revista Brasileira de Zootecnia, v.37, n.11, p.2056- 2062. 2008. 
WALDO, D. R. Extent and partition of cereal grain starch digestion in ruminants. Journal of Animal Science, v.37, n.4, 1973.

ZHANG, G.; ZIHUA, Z.A.; HAMAKER, B.R. Slow digestion property of native cereal starches. Biomacromolecules. v.7, p3252-3258. 2006.

ZINN, R.A.; OWENS, F.N.; WARE, R.A. Flaking corn: processingmechanics, quality standards, and impacts on energy availability andperformance of feedlot cattle. Journal of Animal Science, v.80, p.1145-1156, 2002. 


\section{CAPITULO 2}

CONSUMO E DIGESTIBILIDADE APARENTE DA MATÉRIA SECA E NUTRIENTES, PH, N-NH3, GLICOSE SANGUÍNEA E MICROSCOPIA ELETRONICA DE VARREDURA EM GRANULOS DE MILHO 


\section{RESUMO}

Eduardo Guimarães Brandão ${ }^{1}$, Clayton Quirino Mendes ${ }^{1}$

${ }^{1}$ Faculdade de Agronomia e Medicina Veterinária da Universidade de Brasília, DF.

Objetivou-se avaliar os efeitos da reconstituição da umidade com solução alcalina $(\mathrm{NaOH})$ e salina $(\mathrm{NaCl})$ associada à moagem grosseira dos grãos de milho sobre o consumo, a digestibilidade aparente dos nutrientes e os parâmetros ruminais de ovinos. Foram utilizados 12 ovinos machos, mestiços, castrados e fistulados no rúmen. Os animais foram distribuídos em delineamento inteiramente casualizado, mantidos em gaiolas para ensaio de metabolismo e distribuídos em quatro tratamentos: controle - milho moído sem reconstituição; $\mathrm{NaOH}$ - milho moído e reconstituído com solução alcalina a 0,5\%; 50 $\mathrm{NaOH}: 50 \mathrm{NaCl}$ - milho moído e reconstituído com $50 \%$ de solução alcalina a $0,5 \%+50 \%$ de solução salina a $10 \%$; e $\mathrm{NaCl}$ - milho moído e reconstituído com solução salina a $10 \%$. As dietas experimentais foram compostas por feno de Tifton-85 e concentrado na proporção 40:60. Foram avaliados o consumo e a digestibilidade aparente dos nutrientes, o pH ruminal, a concentração de nitrogênio amoniacal e o teor de glicose no plasma sanguíneo e os grânulos de amido a partir da microscopia eletrônica de varredura. $\mathrm{O}$ tratamento com $\mathrm{NaCl}$ apresentou maior consumo $(\mathrm{P}<0,05)$ para extrato etéreo e amido , mas não apresentou variações em suas digestibilidades. Não houve efeito dos tratamentos sobre o pH ruminal e a concentração de glicose plasmática. Houve maior concentração de nitrogênio amoniacal no tratamento com $\mathrm{NaCl}$. Microscopicamente as estruturas dos grânulos de amido não foram afetadas pelos tipos de reconstituição, apenas se observou um espaçamento e irregularidade entre os grânulos em relação ao tratamento controle. A reconstituição de grãos de milho com as concentrações das soluções utilizadas no presente trabalho não apresentou vantagens qualitativas em relação ao milho não reconstituído. 
Palavras-chave: cloreto de sódio, grânulo de amido, hidróxido de sódio, milho reconstituído, $\mathrm{pH}$ ruminal. 


\begin{abstract}
Eduardo Guimarães Brandão ${ }^{1}$, Clayton Quirino Mendes ${ }^{1}$

${ }^{1}$ School of Agronomy and Veterinary Medicine - University of Brasilia, DF.
\end{abstract}

The objective of this trial was to evaluate the effects of moisture replenishment with alkaline solution $(\mathrm{NaOH})$ and salt $(\mathrm{NaCl})$ associated with the coarse grinding of corn kernels on intake, apparent nutrient digestibility and ruminal characteristics of sheep. Twelve male sheep crossbred, castrated and rumen canuleted were used. Animals were distributed in a completely randomized design, housed in metabolic cages and test for four treatments: control - ground corn without reconstruction; $\mathrm{NaOH}$ - milled corn and reconstituted with alkaline solution at 0,5\%; $50 \mathrm{NaOH}$ : $\mathrm{NaCl} 50$ - milled corn and reconstituted with $50 \%$ bleach solution $+50 \%$ brine; $\mathrm{NaCl}$ - milled corn and reconstituted with saline solution at $10 \%$. The experimental diets were composed by $40 \%$ of Tifton- 85 hay and $60 \%$ of concentrated. Were evaluated intake and apparent digestibility of nutrients, ruminal $\mathrm{pH}$, ammonia nitrogen and blood plasma glucose concentration. Also the starch granules from the scanning electron microscopy. Treatment with $\mathrm{NaCl}$ showed higher $(\mathrm{P}<0,05)$ for ether extract and starch intake, but no differences in their digestibility. There was no treatments effect on ruminal $\mathrm{pH}$ and plasma glucose concentration. A higher concentration of ammonia nitrogen was verified in the treatments containing $\mathrm{NaCl}$. Microscopically the structures of starch granules were not affected by the types of reconstruction, only there was irregularity and spacing among beads compared to the control treatment. Reconstitution of corn grain with of the solutions used in this study did not show qualitative advantages.

Keywords: cloreto de sódio, grânulo de amido, hidróxido de sódio, milho reconstruído, pH ruminal. 


\section{INTRODUÇÃO}

O milho é a principal fonte de energia utilizada em dietas para ruminantes. No entanto, seu aproveitamento está diretamente influenciado pelos métodos de processamento a que é submetido (THEURER, 1986). O processamento do milho serve para expor os grânulos de amido à digestão (BEAUCHEMIN et al. 1994), formando fissuras, fracionando, ou expandindo o amido, por meio da eliminação da película externa do grão, o pericarpo, que constitui uma barreira física que dificulta o ataque microbiano e a ação das enzimas digestivas do animal (KOTARSKI et al. 1992).

$\mathrm{O}$ efeito do processamento em grãos pode afetar a digestibilidade e a taxa de digestão do amido do milho, assim como o consumo de volumoso. É conhecido que todos os tipos de processamento são utilizados na intenção de melhorar a conversão alimentar. Quando o processamento de grão não é utilizado, pode ocorrer um desperdício de energia, assim como no uso de grãos inteiros, que apesar de reduzir a velocidade de produção dos ácidos graxos de cadeia curta, aumento da produção de saliva e um consequente efeito tampão, acarreta em grande perda dos grãos que passam parcialmente íntegros pelo trato digestivo (FAHEY e BERGER, 1993).

A escolha de soluções específicas que afetem a matriz proteica que envolve os grânulos de amido (albuminas, proteínas solúveis em água; globulinas que podem ser extraídas com solução salina; com álcool e água, as prolaminas) auxilia na disponibilidade do amido (SILVA et al. 2013). Dessa forma, dentre os diversos tipos de processamentos que

podem utilizados, a reconstituição dos grãos de milho moído grosseiramente surge como alternativa.

Objetivou-se com este trabalho avaliar os efeitos da reconstituição da umidade dos grãos de milho com solução alcalina $(\mathrm{NaOH})$ e salina $(\mathrm{NaCl})$ sobre o consumo, a digestibilidade aparente dos nutrientes e os parâmetros ruminais de ovinos. 


\section{MATERIAL E MÉTODOS}

\subsection{Local, animais e tratamentos}

$\mathrm{O}$ experimento foi realizado no Centro de Manejo de Ovinos (CMO), as análises realizadas no Laboratório de Nutrição Animal (LNA), ambos localizados na Fazenda Água Limpa, de propriedade da Universidade de Brasília (UnB), situada no Núcleo Rural Vargem Bonita, Brasília, Distrito Federal (DF) a $15^{\circ} 47^{\prime}$ de latitude sul e $47^{\circ} 56^{\prime}$ de longitude oeste e altitude média de $1080 \mathrm{~m}$. O clima da região é do tipo AW pela classificação de Koppen, com temperatura media anual de $23{ }^{\circ} \mathrm{C}$, tendo $16^{\circ} \mathrm{C}$ e $34{ }^{\circ} \mathrm{C}$ como mínima e máxima absoluta, respectivamente. A precipitação anual é de $1.300 \mathrm{~mm}$ e a média anual de umidade relativa do ar é de $66 \%$.

Foram utilizados 12 ovinos machos, mestiços, castrados e fistulados no rúmen, com idade média de 36 meses e com peso médio de $50 \mathrm{~kg}$. Inicialmente, os animais foram pesados, identificados e tratados contra endo e ectoparasitas, sendo alojados individualmente em gaiolas para ensaio de metabolismo providas de bebedouro e comedouro (Figura 3). Os animais foram distribuídos em delineamento inteiramente casualizado, divididos em quatro tratamentos (tipo de reconstituição do grão de milho) com três repetições (animais).

Os tratamentos foram compostos pela combinação de diferentes formas de reconstituição do milho tipo duro, moído em peneira de $5 \mathrm{~mm}$ : 1) Controle - Milho moído sem reconstituição; 2) $\mathrm{NaOH}$ - Milho moído e reconstituído com solução alcalina; 3) 50 $\mathrm{NaOH}: 50 \mathrm{NaCl}$ - Milho moído e reconstituído com 50\% de solução alcalina $+50 \%$ de solução salina e, 4) $\mathrm{NaCl}$ - Milho moído e reconstituído com solução salina. 


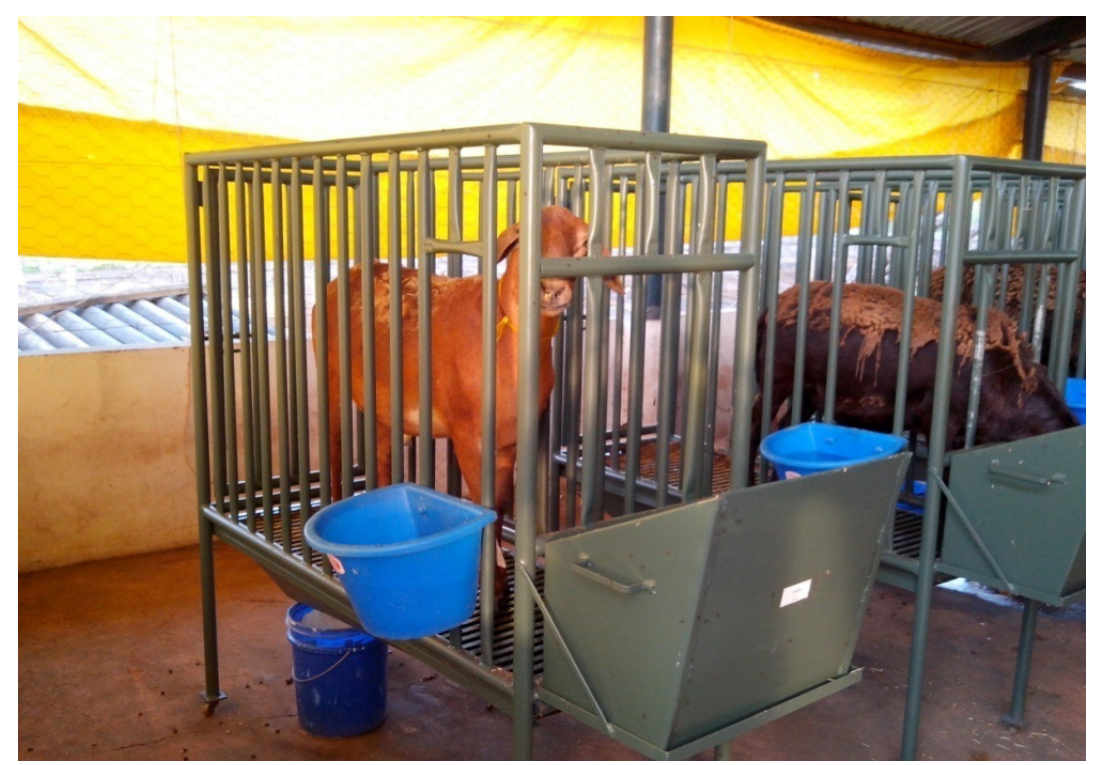

Figura 3: Gaiola para ensaio de metabolismo

Fonte: Arquivo pessoal

A solução alcalina foi composta de água destilada $+0,5 \%$ de $\mathrm{NaOH}$ e teve o objetivo de solubilizar as gluteínas. A solução salina foi composta de água destilada $+10 \%$ de $\mathrm{NaCl}$ e teve objetivo de solubilizar as globulinas.

Para que ocorresse a reconstituição, o teor de umidade foi elevado de 5,8\% para $35 \%$. Os procedimentos foram baseados na equação, adaptada de Ferreira (1983):

$$
\Delta \mathrm{H} 2 \mathrm{O}=\left(\left[\mathrm{MU}^{*}((\mathrm{Uf}-\mathrm{Ui})) /(100-\mathrm{Ui})\right]\right) /(\rho)
$$

Em que: $\Delta \mathrm{H} 2 \mathrm{O}=$ Volume de água a ser adicionado (litros); $\mathrm{MU}=$ Massa do produto úmido $(\mathrm{kg}) ; \mathrm{Uf}=$ Umidade final (\% base úmida); $\mathrm{Ui}=$ Umidade inicial ( $\%$ base úmida); $\rho=$ Massa específica da água $(\mathrm{kg} / \mathrm{L})$.

Ao milho moído (Figura 4) foi adicionada solução alcalina, solução mista (50\% alcalina: 50\% salina) ou solução salina, seguido de período de descanso por 24 horas em baldes específicos para cada tratamento (Figura 5). Posteriormente ao período de descanso foi adicionado o restante dos ingredientes da dieta.

A alimentação foi fornecida duas vezes ao dia, as 09:00 e as 17:00 horas, e ajustada de forma a manter as sobras em até $10 \%$ do oferecido. As dietas experimentais foram formuladas de acordo com as recomendações do NRC (2007) para atender as exigências nutricionais de machos adultos e castrados. As dietas foram compostas por feno de Tifton -85 picado em peneira de $1 \mathrm{~cm}$ e concentrado na proporção de 40:60 (Tabela 1). 


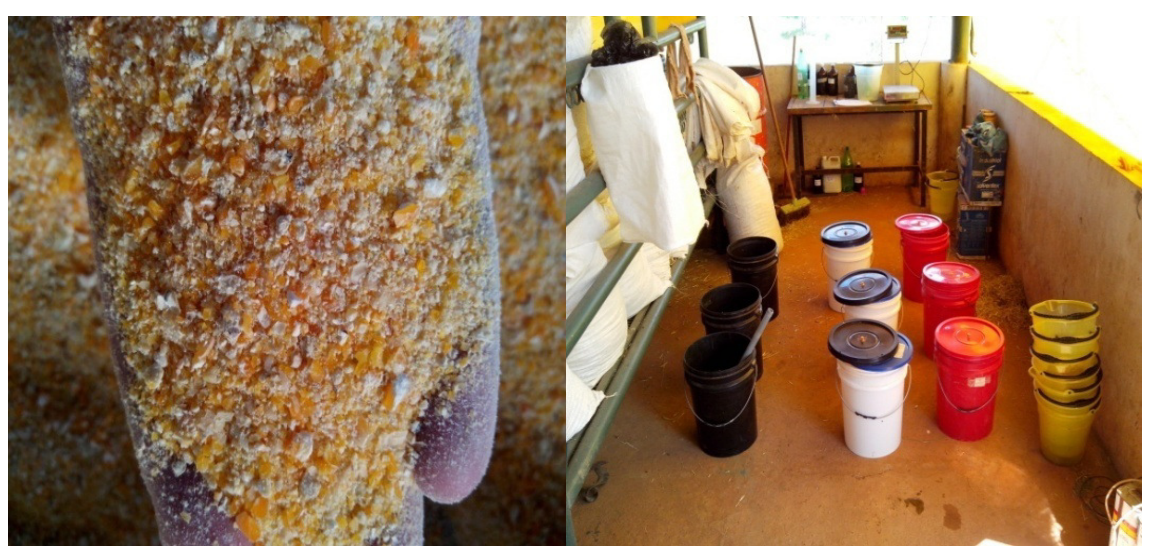

Figura 4: Milho moído

Figura 5: Baldes com tratamentos

Fonte: Arquivo pessoal

Fonte: Arquivo pessoal

Tabela 1. Proporção dos ingredientes e composição nutricional das dietas experimentais.

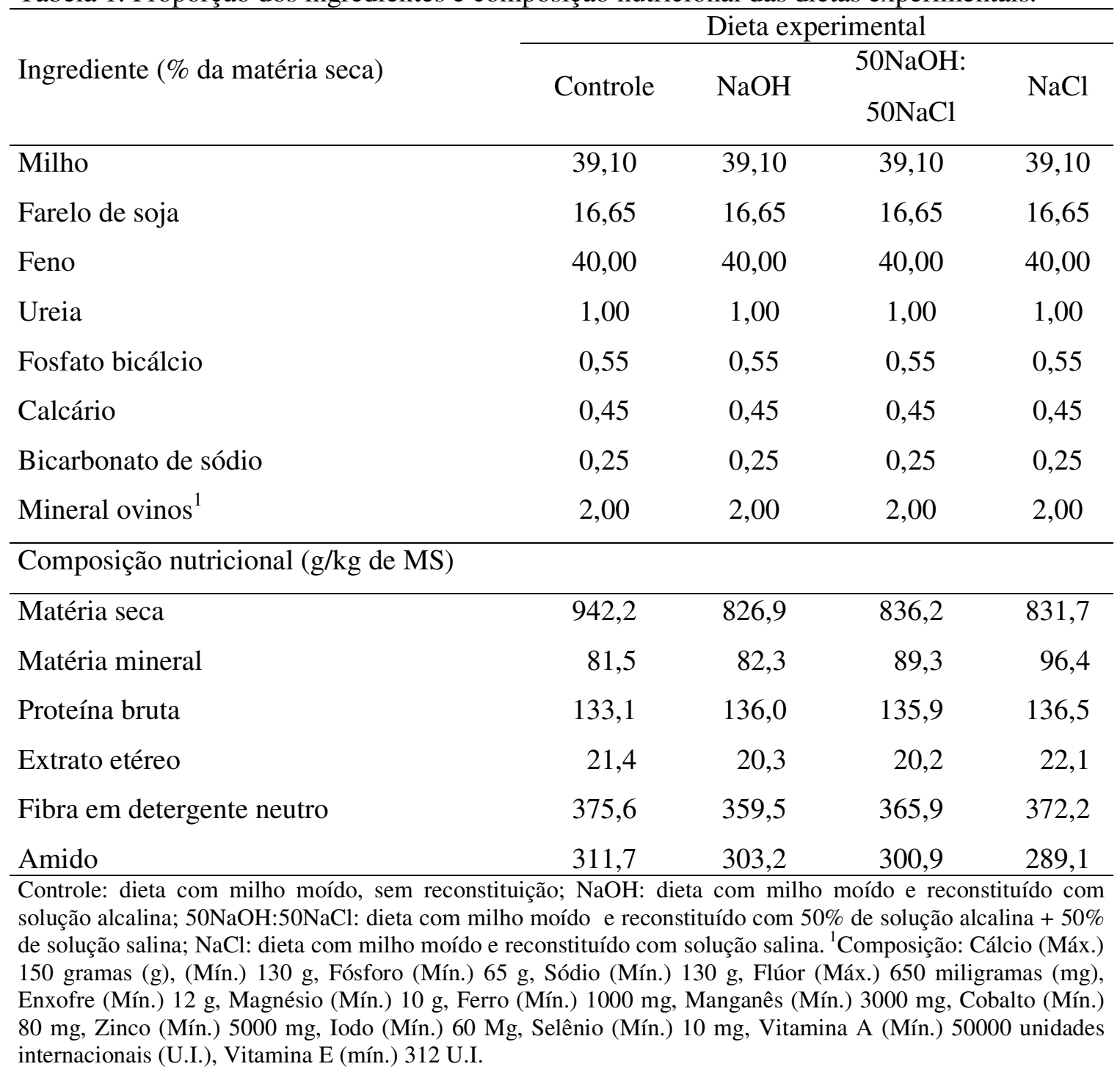


Os valores das análises bromatológicas dos ingredientes utilizados estão descritos na Tabela 2.

Tabela 2. Composição bromatológica do milho, do farelo de soja e do feno ( $\mathrm{g} / \mathrm{kg}$ da matéria seca).

\begin{tabular}{|c|c|c|c|c|c|c|}
\hline \multirow[b]{2}{*}{ Componentes } & \multicolumn{4}{|c|}{ Milho } & \multirow[b]{2}{*}{$\begin{array}{l}\text { Farelo de } \\
\text { Soja }\end{array}$} & \multirow[b]{2}{*}{ Feno } \\
\hline & Controle & $\mathrm{NaOH}$ & $\begin{array}{c}50 \mathrm{NaOH} \\
50 \mathrm{NaCl}\end{array}$ & $\mathrm{NaCl}$ & & \\
\hline Matéria seca & 941,9 & 647,2 & 670,8 & 659,4 & 903,8 & 962,4 \\
\hline Matéria mineral & 11,4 & 13,4 & 31,4 & 49,6 & 78,7 & 53,6 \\
\hline Matéria orgânica & 930,5 & 633,8 & 639,4 & 609,9 & 825,1 & 908,9 \\
\hline Proteína Bruta & 85,6 & 93,0 & 92,8 & 94,3 & 479,6 & 48,7 \\
\hline Extrato Etéreo & 38,5 & 35,7 & 35,5 & 40,1 & 24,8 & 5,6 \\
\hline Fibra em detergente neutro & 128,7 & 92,8 & 109,1 & 125,2 & 116,8 & 759,5 \\
\hline Fibra em detergente ácido & 51,7 & 33,1 & 38,4 & 42,6 & 88,1 & 330,8 \\
\hline Amido & 678,8 & 657,2 & 651,3 & 621,0 & 16,9 & 108,6 \\
\hline Lignina & 13,6 & 9,8 & 11,2 & 11,5 & 18,6 & 52,5 \\
\hline Carboidratos totais, $\% \mathrm{MS}$ & 86,45 & 85,78 & 84,03 & 81,6 & 41,69 & 89,21 \\
\hline Carboidratos não fibrosos, \%MS & 73,58 & 76,51 & 73,13 & 69,07 & 30,01 & 13,26 \\
\hline \multicolumn{7}{|l|}{ Valores estimados de energia } \\
\hline Nutrientes digestíveis totais, $\%$ & 88,01 & 88,81 & 86,47 & 84,83 & 79,9 & 59 \\
\hline Energia digestível, Mcal/kg & 3,88 & 3,92 & 3,81 & 3,74 & 3,52 & 2,6 \\
\hline Energia metabolizável, Mcal/kg & 3,47 & 3,5 & 3,4 & 3,33 & 3,11 & 3,11 \\
\hline Energia líquida, Mcal/kg & 2,22 & 2,24 & 2,18 & 2,14 & 2,01 & 1,45 \\
\hline
\end{tabular}

MControle: milho moído sem reconstituição; $\mathrm{MNaOH}$ : milho moído e reconstituído com solução alcalina; M50NaOH:50NaCl: milho moído e reconstituído com $50 \%$ de solução alcalina $+50 \%$ de solução salina;M $\mathrm{NaCl}$ : milho moído e reconstituído com solução salina; ${ }^{1}$ Equação: NDTm $=(\mathrm{PBD}+\mathrm{CNFD}+\mathrm{FDND}+\mathrm{EED} x$ $2,25)-7$.

\subsection{Período experimental e amostragem}

O experimento teve duração de 21 dias, sendo 14 dias destinados à adaptação dos animais as gaiolas e à dieta, cinco dias destinados à medição do consumo de matéria seca e coleta total de fezes, no $20^{\mathrm{a}}$ dia destinado à avaliação de parâmetros ruminais de $\mathrm{pH}$ e nitrogênio amoniacal,e o último dia para coleta de sangue.

Antes do fornecimento da dieta as sobras foram colhidas e pesadas em balança analítica, sendo uma amostra retirada e armazenada a $-20^{\circ} \mathrm{C}$, para formar amostras compostas representando cada tratamento.

Foi colocada uma bolsa de coleta para fezes nos animais para mensuração da produção total de fezes no período de 24 horas (Figura 6) do $15^{\circ}$ ao $19^{\circ}$ dia. 


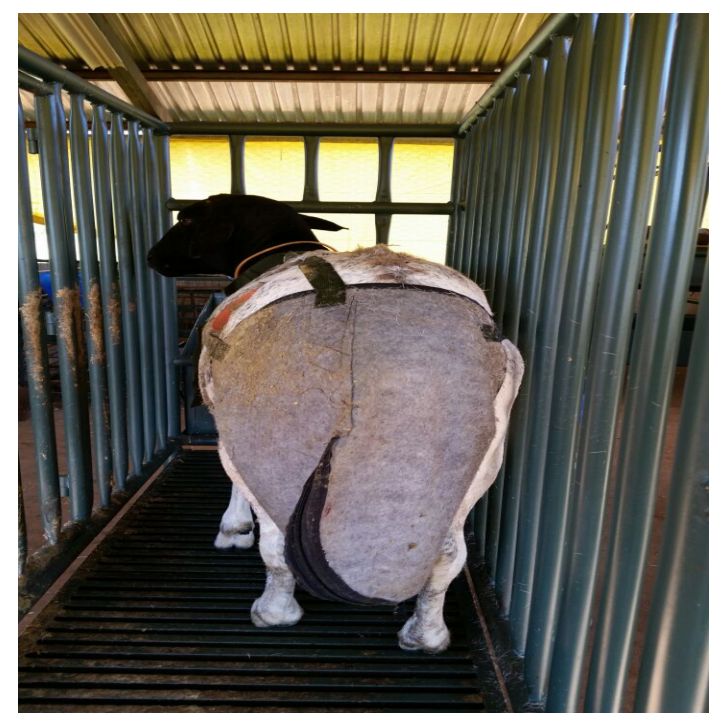

Figura 6: Bolsa de coleta de fezes

Fonte: Arquivo pessoal

As fezes foram pesadas diariamente em balança analítica e sendo amostrados $10 \%$ do coletado, misturando com as dos outros dias, e armazenada a $-20^{\circ} \mathrm{C}$. Com duas coletas durante o dia a fim de aliviar o peso das bolsas.

Posteriormente, as amostras do fornecido, sobras e fezes foram pré-secas em estufa de circulação forçada de ar a $60^{\circ} \mathrm{C}$, por 72 horas, sendo realizada a moagem com peneira de malha de $1 \mathrm{~mm}$, para posteriores análises laboratoriais.

\subsection{Amido fecal}

Uma alíquota do pool derivado das coletas de fezes entre o $15^{\circ}$ ao $19^{\circ}$ de experimento de cada animal, posteriormente descongelada e seca em estufa de $65^{\circ}$ e encaminhada para o laboratório para analises. A percentagem de amido foi determinada por leitura da quantidade de dextrose na amostra de fezes através de uma enzima ativa, chamada de amiloglucosidase, responsável por extrair a molécula de amido, de acordo com as técnicas citadas por Hall (2008).

\subsection{Aferição do pH ruminal}

No $20^{\circ}$ dia do experimento foram colhidos $100 \mathrm{ml}$, aproximadamente, de líquido ruminal via cânula para aferição do $\mathrm{pH}$, imediatamente antes do fornecimento da dieta (tempo 0) e 2, 4 e 6 horas após a alimentação. Fazendo-se a leitura imediatamente com auxílio 
de um potenciômetro digital para aferição de $\mathrm{pH}$ e temperatura em meios semi-sólidos de modelo: Testo $205 \mathrm{pH} /{ }^{\circ} \mathrm{C}$ (Figura 7).

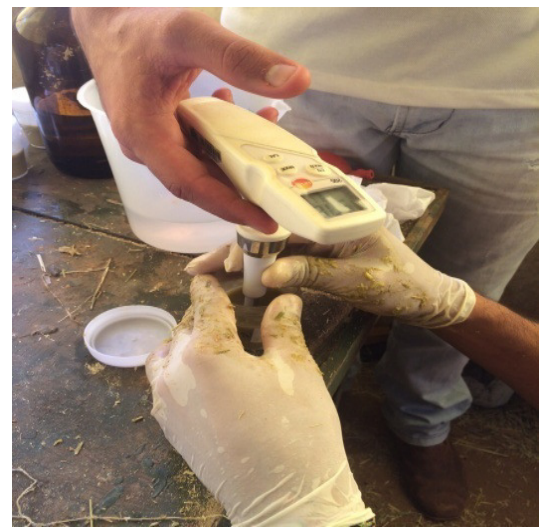

Figura 7: Aferição do $\mathrm{pH}$

Fonte: Arquivo pessoal

\subsection{Nitrogênio amoniacal}

No mesmo dia e horas das coletas de líquido ruminal para a aferição do $\mathrm{pH}$, foram recolhidos $50 \mathrm{ml}$ deste líquido ruminal, anteriormente filtrado em gazes duplas, e acondicionado em frasco e identificado de acordo com animal e tempo de coleta $(0 ; 2 ; 4$ e 6 horas) e congelados $\mathrm{a}-20^{\circ} \mathrm{C}$ para posterior análise.

Para a determinação do nitrogênio amoniacal $\left(\mathrm{N}-\mathrm{NH}_{3}\right)$ as amostras foram descongeladas a temperatura ambiente e em seguida foram analisadas de acordo com a técnica da reação colorimétrica catalasida por indofenol descrita por Detmann et al. (2012), no espectrofotômetro da marca GEHAKA, modelo UV-340G.

\subsection{Análise de glicose}

No $21^{\circ}$ dia de experimento, quatro horas após o trato, o sangue foi coletado pela veia jugular em tubo Vacuette ${ }^{\circledR}$ específico para análise glicêmica, identificado e armazenado em caixa de isopor com gelo e encaminhado para o Laboratório de Patologia Veterinária do Hospital Veterinário de Pequenos Animais da Universidade de Brasília, e analisado no Analisador Bioquímico Semiautomático BIOPLUS-200.

\subsection{Análises bromatológicas}


Para as amostras de milho, farelo de soja e feno foram feitas as análises de matéria seca (MS), matéria orgânica (MO), matéria mineral (MM), compostos nitrogenados (N) e extrato etéreo (EE) seguindo as especificações da American of Official Analytical Chemists - AOAC (1990). Fibra em detergente neutro (FDN) em amilase termoestável, fibra em detergente ácido (FDA) e lignina em detergente ácido (LDA), segundo Van Soest et al. (1991). Amido de acordo com as técnicas citadas por Hall (2008). Também foram feitas as análises de nitrogênio insolúvel em detergente neutro (NIDN) e nitrogênio insolúvel em detergente ácido (NIDA), de acordo com técnicas descritas por Licitra et al. (1996).

Os carboidratos totais (CHOT) e carboidratos não fibrosos (CNF) foram calculados segundo Sniffen et al. (1992) e Van Soest et al. (1991), respectivamente: CHOT = $100-(\% \mathrm{~PB}+\% \mathrm{EE}+\%$ Cinzas $)$ e $\mathrm{CNF}=(100-(\% \mathrm{~PB}+\% \mathrm{EE}+\%$ Cinzas $+\% \mathrm{FDN})$

Os valores estimados de nutrientes digestíveis totais (NDT) para o nível de mantença (NDTm), de NDT para o nível de produção (NDTp) e de energia líquida para o nível de produção (ELp) do milho processado foram obtidos segundo as equações descritas no NRC (2001).

$$
\begin{aligned}
& \mathrm{NDTm}=(\mathrm{PBD}+\mathrm{CNFD}+\mathrm{FDND}+\mathrm{EED} \times 2,25)-7, \text { em que: } \\
& \mathrm{PBD}=[1-(0,4 \times \mathrm{PIDA} / \mathrm{PB})] \times \mathrm{PB}-\text { para concentrados; } \\
& \mathrm{PBD}=\mathrm{PB} * \exp (-1,2 * \mathrm{PIDA} / \mathrm{PB})-\text { para volumosos; } \\
& \mathrm{CNFD}=0,98 \times \mathrm{CNF} ; \\
& \mathrm{FDND}=0,75 \times(\mathrm{FDNcp}-\mathrm{LDA}) \times[1-(\mathrm{LDA} / \mathrm{FDNcp}) 0,667] ; \\
& \mathrm{EED}=\mathrm{EE}-1 ; \\
& 0,75=\text { constante de proporcionalidade; } \mathrm{e} 7 \text { refere-se ao NDT metabólico fecal. }
\end{aligned}
$$

Sendo PBD (PB verdadeiramente digestível); CNFD (CNF verdadeiramente digestível); FDND (FDN verdadeiramente digestível); AGD (AG verdadeiramente digestíveis); LDA (lignina em detergente ácido).

Os valores de NDT foram convertidos em energia digestível (ED) e energia metabolizável (EM) utilizando-se as equações sugeridas pelo NRC (2001):

$$
\begin{aligned}
& \operatorname{ED}(\mathrm{Mcal} / \mathrm{kg})=0,04409 \times \mathrm{NDT}(\%) \\
& \operatorname{EM}(\mathrm{Mcal} / \mathrm{kg})=1,01 \times \mathrm{ED}(\mathrm{Mcal} / \mathrm{kg})-0,45 ;
\end{aligned}
$$

A conversão do NDT em energia líquida foi feita pela equação de Moe et al. (1972), que corresponde a energia líquida ao nível de mantença: ELm (Mcal/kg) = 0,0266 x $\operatorname{NDT}(\%)-0,12$

O preparo das amostras compostas das sobras diárias e fezes de cada animal e as análises de matéria seca (MS), matéria orgânica (MO), matéria mineral (MM), compostos nitrogenados $(\mathrm{N})$, extrato etéreo (EE) seguiram as especificações da American of Official 
Analytical Chemists - AOAC (1990). Fibra em detergente neutro (FDN) em amilase termoestável e fibra em detergente ácido (FDA), segundo Van Soest et al. (1991).

\subsection{Microscopia eletrônica}

A microscopia eletrônica foi utilizada para estudar as características de forma, tamanho dos grânulos e distribuição do amido. Assim, amostras de milho dos quatro tratamentos foram secas em estufa a $105{ }^{\circ} \mathrm{C}$ e preparados para observação em microscopia eletrônica de varredura. Devido ao fato das amostras já estarem secas não foi necessário à fixação com glutaraldeído e paraformaldeído, em tampão fosfato (KARNOVSKY, 1965). Assim, as amostras foram cobertas com ouro em metalizador (FDU 010, Bal-Tec, Balzers, Liechtenstein). A captura de imagens foi realizada em um microscópio eletrônico de varredura com câmera digital acoplada (Zeiss, LEO 1430 VP), localizado no Laboratório de Microscopia e Eletrônica e Virologia no Instituto de Biologia da Universidade de Brasília.

\subsection{Digestibilidade aparente}

As equações utilizadas para os cálculos da digestibilidade aparente da matéria seca (DMS) e dos nutrientes (DN) foram de acordo com as citadas por Silva e Leão (1979). DMS $(\%)=($ MS ingerida - MS excretada/MS ingerida $) \times 100$ e DN $(\%)=[($ MS ingerida $\mathrm{x} \%$ Nutriente) - (MS excretada x \% Nutriente)/(MS ingerida x \% Nutriente)] x 100

\subsection{Análises estatísticas}

As análises estatísticas foram realizadas utilizando-se o pelo PROC GLM do programa computacional SAS versão 9.2 (2008). Foram realizadas análises de variância e após verificação da significância do teste $\mathrm{F}$ as médias foram submetidas ao teste de Tukey, adotando-se 5\% de significância, de acordo com o seguinte modelo: Yijk $=\mu+\mathrm{Di}+\mathrm{ak}+$ eijk, em que $\mu=$ média geral; $\mathrm{Di}=$ efeito fixo da dieta; ak = efeito aleatório do animal e eijk $=$ erro experimental da parcela. Para os dados de $\mathrm{pH}$ eN-NH3, o delineamento utilizado foi em parcelas subdivididas, sendo os tratamentos considerados como parcelas e os tempos de coleta como subparcelas. 


\section{RESULTADOS E DISCUSSÃO}

Houve efeito dos tratamentos sobre o consumo de extrato etéreo e de amido (Tabela 3), o qual foi maior para o tratamento com $\mathrm{NaCl}$ em relação ao tratamento em que o $\mathrm{NaCl}$ foi combinado com o $\mathrm{NaOH}$. Além disso, observou-se tendência de comportamento semelhante para o consumo de matéria seca $(\mathrm{P}=0,0660)$, de proteína bruta $(\mathrm{P}=0,0519)$ e de fibra em detergente neutro $(\mathrm{P}=0,0811)$. Em relação à digestibilidade não houve efeito do tratamento em nenhum dos parâmetros avaliados.

$\mathrm{O}$ maior consumo de extrato etéreo para o tratamento $\mathrm{NaCl}$ em relação ao tratamento $50 \mathrm{NaOH}: 50 \mathrm{NaCl}$ pode estar relacionado ao maior teor desse componente na dieta contendo o milho reconstituído com $\mathrm{NaCl}$ (Tabela 1), fator que não limitou o consumo. Lana (2000) relata que não se deve ultrapassar o nível de 5\% de extrato etéreo na dieta de bovinos de corte, devido ao efeito negativo na digestibilidade da fibra.

Malafaia et al. (2012) relataram que o uso crescente de $\mathrm{NaCl}$ (até $90 \mathrm{~g} / \mathrm{dia}$ ) na dieta de bezerras seria capaz de ampliar o consumo de matéria seca de 2,2\% para $2,4 \%$ em relação ao peso vivo. Rabelo et al. (2013) relataram maior ingestão de matéria seca para dietas compostas por silagens de cana-de-açúcar tratadas com $0,5 \%$ de $\mathrm{NaCl}$ e $1 \%$ de $\mathrm{CaO}$. O consumo observado no presente estudo para o tratamento controle $(1,73 \mathrm{~kg} / \mathrm{dia})$ foi superior ao citado por Medeiros et al. (2007), que relataram valor de 1,00 kg/dia para cordeiros castrados da raça Morada Nova mantidos em confinamento com dieta contendo a mesma proporção de volumoso:concentrado (40:60). A digestibilidade da matéria seca relatada por esses s autores $(73,35 \%)$ foi semelhantes à encontrada no presente trabalho $(70,5 \%)$.

A digestibilidade da matéria seca para o tratamento $\mathrm{NaOH}$ não apresentou efeito positivo em relação aos demais tratamentos, mesmo com à ação tamponante que a solução alcalina utilizada na reconstituição do milho causa no rúmen, contrariando desta forma resultados obtidos por Gastaldello Jr. et al. (2013), que utilizando agentes tamponantes como bicarbonato de sódio e de fontes de calcário em dietas contento alto concentrado 
relataram maior digestibilidade da matéria seca. Resultados encontrados por outros autores que demonstraram que a utilização de produtos alcalinos como o $\mathrm{NaOH}$ e o $\mathrm{CaO}$ (cal) em volumosos aumentaram a digestibilidade da matéria seca (OLIVEIRA et al. 2002; PIRES et al. 2004; EZEQUIEL et al. 2005; PIRES et al. 2006; OLIVEIRA et al. 2007).

Tabela 3. Consumo e digestibilidade aparente da matéria seca e dos nutrientes da dieta.

Dieta experimental

\begin{tabular}{|c|c|c|c|c|c|c|}
\hline Variável & Controle & $\mathrm{NaOH}$ & $\begin{array}{l}50 \mathrm{NaO} \\
50 \mathrm{NaC}\end{array}$ & $\mathrm{NaCl}$ & $P$ & EPM \\
\hline & \multicolumn{4}{|c|}{ Consumo (g/dia) } & & \\
\hline Matéria seca & $1.732,0$ & $1.865,0$ & $1.696,3$ & 2086,5 & 0,0660 & 149,9 \\
\hline Proteína bruta & 241,8 & 259,3 & 236,0 & 292,3 & 0,0519 & 20,3 \\
\hline Extrato etéreo & $35,3^{\mathrm{ab}}$ & $38,2^{\mathrm{ab}}$ & $33,6^{\mathrm{b}}$ & $45,3^{\mathrm{a}}$ & 0,0403 & 3,9 \\
\hline Fibra detergente neutro & 628,7 & 658,2 & 575,1 & 726,0 & 0,0811 & 54,0 \\
\hline Carboidratos totais & $1.314,9$ & $1.414,0$ & $1.275,7$ & $1.546,3$ & 0,1009 & 113,1 \\
\hline Carboidratos não fibrosos & 686,2 & 755,8 & 700,6 & 820,3 & 0,1645 & 67,8 \\
\hline Amido & $539,8^{\mathrm{ab}}$ & $565,5^{\mathrm{ab}}$ & $510,4^{\mathrm{b}}$ & $603,1^{\mathrm{a}}$ & 0,0386 & 38,2 \\
\hline \multirow[t]{2}{*}{ Nutrientes digestíveis totais } & $1.136,6$ & $1.199,6$ & $1.143,1$ & $1.349,4$ & 0,1539 & 107,9 \\
\hline & \multicolumn{4}{|c|}{ Digestibilidade aparente (\%) } & & \\
\hline Matéria seca & 70,5 & 68,7 & 72,3 & 71,1 & 0,1937 & 1,7 \\
\hline Proteína bruta & 72,7 & 70,3 & 78,3 & 77,2 & 0,3360 & 5,3 \\
\hline Extrato etéreo & 51,0 & 64,7 & 61,2 & 48,8 & 0,1016 & 7,3 \\
\hline Fibra detergente neutro & 51,0 & 50,8 & 55,5 & 56,0 & 0,3800 & 4,3 \\
\hline Carboidratos totais & 71,6 & 70,2 & 73,4 & 71,3 & 0,5190 & 2,2 \\
\hline Carboidratos não fibrosos & 90,2 & 87,0 & 88,1 & 84,9 & 0,1067 & 2,2 \\
\hline Amido & 98,2 & 98,9 & 98,6 & 98,0 & 0,6225 & 0,9 \\
\hline
\end{tabular}

Controle: dieta com milho moído sem reconstituição; $\mathrm{NaOH}$ : dieta com milho moído e reconstituído com solução alcalina; $50 \mathrm{NaOH}: 50 \mathrm{NaCl}$ : dieta com milho moído e reconstituído com $50 \%$ de solução alcalina $+50 \%$ de solução salina; $\mathrm{NaCl}$ : dieta com milho moído e reconstituído com solução salina; ${ }^{1} \mathrm{NDT}=\mathrm{CPB} * \mathrm{DPB} / 100+$ CEE*DEE/100 + CFDN*DFDN/100 + CCNF*DCNF/100; a,b,c - Médias seguidas de letras diferentes nas linhas, são diferentes pelo teste de Tukey com 95\% de confiabilidade; erro padrão da média (EPM).

Em relação ao consumo de amido, o mesmo está diretamente relacionado à tendência do consumo de matéria seca relatado anteriormente, uma vez que o milho tratado que $\mathrm{NaCl}$ apresentou menor concentração de amido (Tabela 2). Sandhu et al. (2008) e Spier (2010) encontraram redução significativa no teor de amilose do amido do milho devido ação 
alcalina do hipoclorito de sódio na concentração de 1 e $2 \%$, respectivamente. Mesmo com as diferenças de consumos não foi observada variação na digestibilidade do amido entre os tratamentos. A digestibilidade do amido das dietas foi em média 98,4\%, valor similar aos 99,4\% encontrado por Queiroz et al. (2008) ao avaliarem o desempenho de cordeiros alimentados com diferentes fontes proteicas em dietas com $90 \%$ de concentrado.

A tendência de variação do consumo de proteína bruta para o tratamento $\mathrm{NaCl}$ é reflexo, além do maior consumo de matéria seca, da maior teor de proteína bruta no milho reconstituído com solução salina (Tabela 2). Paulis e Wall (1977) utilizaram $\mathrm{NaCl}$ a 0,5M para extrair as proteínas do endosperma do milho solúveis em sal (globulinas) e obtiveram 4\% a mais do total de nitrogênio. Rabelo et al. (2013) também relataram maior consumo de proteína bruta $(\mathrm{P}<0,05)$ com a adição de $1,0 \%$ de $\mathrm{CaO}(\mathrm{kg} / \mathrm{dia})$ e $0,5 \%$ de $\mathrm{NaCl}(\mathrm{kg} / \mathrm{dia})$ na silagem de cana-de-açúcar para ovelhas.

Já o consumo de fibra em detergente neutro está diretamente relacionado com a tendência de maior consumo de matéria seca observada para o tratamento $\mathrm{NaCl}$, uma vez que verificou-se pela observação visual das sobras que os animais que receberam a dieta contendo o milho reconstituído com $\mathrm{NaCl}$ apresentaram maior consumo de feno. Rabelo et al. (2013) relataram maior consumo de fibra em detergente neutro para dietas compostas por silagens de cana-de-açúcar tratadas com $0,5 \%$ de $\mathrm{NaCl}$ e $1 \%$ de $\mathrm{CaO}$, o que foi evidenciado devido a maior ingestão de matéria seca e a ação dos aditivos sobre a fibra da cana. Araújo et al. (2004) relataram que os consumos de matéria seca e de fibra em detergente neutro em cordeiros mantidos em gaiolas para ensaio metabólico submetidos a dietas com teores crescentes de volumosos, aumentaram linearmente com o aumento do nível de consumo e de inclusão de volumosos nas rações.

Não houve efeito da reconstituição dos grãos de milho sobre o pH ruminal, sendo verificado valor médio de 5,92 (Tabela 4). Entretanto, foi detectada variação do pH em relação ao tempo de coleta após alimentação, ocorrendo queda entre os tempos 4 e 6, com valor média de 5,80 em relação ao tempo zero $(6,16)$. Os valores obtidos estão de acordo com Ørskov (1986), pois a redução do pH ruminal ocorre, principalmente após a rápida digestão de dietas ricas em concentrado, devido as elevadas taxas de degradação, atingindo seu menor valor entre 0,5 e 4 horas após alimentação.

As médias obtidas durante o período total de coleta não apresentaram variações entre os tratamentos e os valores, que variaram de 5,63 a 6,34, estão condizentes com a relação volumoso:concentrado de 40:60 utilizados no presente trabalho. De acordo com Valadares Filho e Pina (2006), o pH pode sofrer variação de 5,5 a 7,2. 
Tabela 4. pH ruminal e concentração de nitrogênio amoniacal.

\begin{tabular}{|c|c|c|c|c|c|}
\hline \multirow{2}{*}{ Tempo } & \multicolumn{4}{|c|}{ Tratamento } & \multirow{2}{*}{ Média } \\
\hline & Controle & $\mathrm{NaOH}$ & $50 \mathrm{NaOH}: 50 \mathrm{NaCl}$ & $\mathrm{NaCl}$ & \\
\hline \multicolumn{6}{|c|}{$\mathrm{pH}$ ruminal $(\mathrm{CV}=3,78 \%)$} \\
\hline 0 & 5,97 & 6,25 & 6,01 & 6,34 & $6,16^{\mathrm{a}}$ \\
\hline 2 & 6,12 & 5,98 & 5,74 & 6,05 & $6,00^{\mathrm{ab}}$ \\
\hline 4 & 5,72 & 5,96 & 5,63 & 5,72 & $5,76^{\mathrm{b}}$ \\
\hline 6 & 5,63 & 6,06 & 5,70 & 5,93 & $5,84^{\mathrm{b}}$ \\
\hline Média & 5,85 & 6,06 & 5,77 & 6,00 & \\
\hline \multicolumn{6}{|c|}{$\mathrm{N}^{-\mathrm{NH}_{3}}(\mathrm{mg} / 100 \mathrm{~mL})(\mathrm{CV}=21,95 \%)$} \\
\hline 0 & 15,98 & 16,16 & 18,72 & 23,86 & 18,67 \\
\hline 2 & 17,38 & 14,61 & 19,73 & 23,39 & 18,78 \\
\hline 4 & 14,88 & 13,11 & 17,09 & 23,73 & 17,21 \\
\hline 6 & 14,20 & 14,69 & 14,21 & 14,50 & 14,42 \\
\hline Média & $15,61^{b}$ & $14,64^{\mathrm{b}}$ & $17,48^{\mathrm{b}}$ & $21,36^{\mathrm{a}}$ & \\
\hline
\end{tabular}

Controle: dieta com milho moído sem reconstituição; NaOH: dieta com milho moído e reconstituído com solução alcalina; $50 \mathrm{NaOH}: 50 \mathrm{NaCl}$ : dieta com milho moído e reconstituído com $50 \%$ de solução alcalina $+50 \%$ de solução salina; $\mathrm{NaCl}$ : dieta com milho moído e reconstituído com solução salina; a,b,c - Médias seguidas de letras diferentes nas linhas, são diferentes pelo teste de Tukey com 95\% de confiabilidade; coeficiente de variação(CV).

$\mathrm{O}$ tratamento com $\mathrm{NaOH}$ promoveu uma curva de $\mathrm{pH}$ mais suave que os demais tratamentos (Figura 8). Pina et al. (2010) demonstraram que o comportamento do $\mathrm{pH}$ em função da inclusão de $\mathrm{CaO}$ nos tempos 2,4 e 6 horas foram lineares crescentes $(\mathrm{P}<0,01)$, o que confirmou o efeito alcalinizante da cal no líquido ruminal. Desta forma, a adição de produtos alcalinos na dieta podem exercer efeito tamponante, mantendo o $\mathrm{pH}$ próximo do neutro, permitindo a inclusão de amido na dieta (DIAS, 2009). 


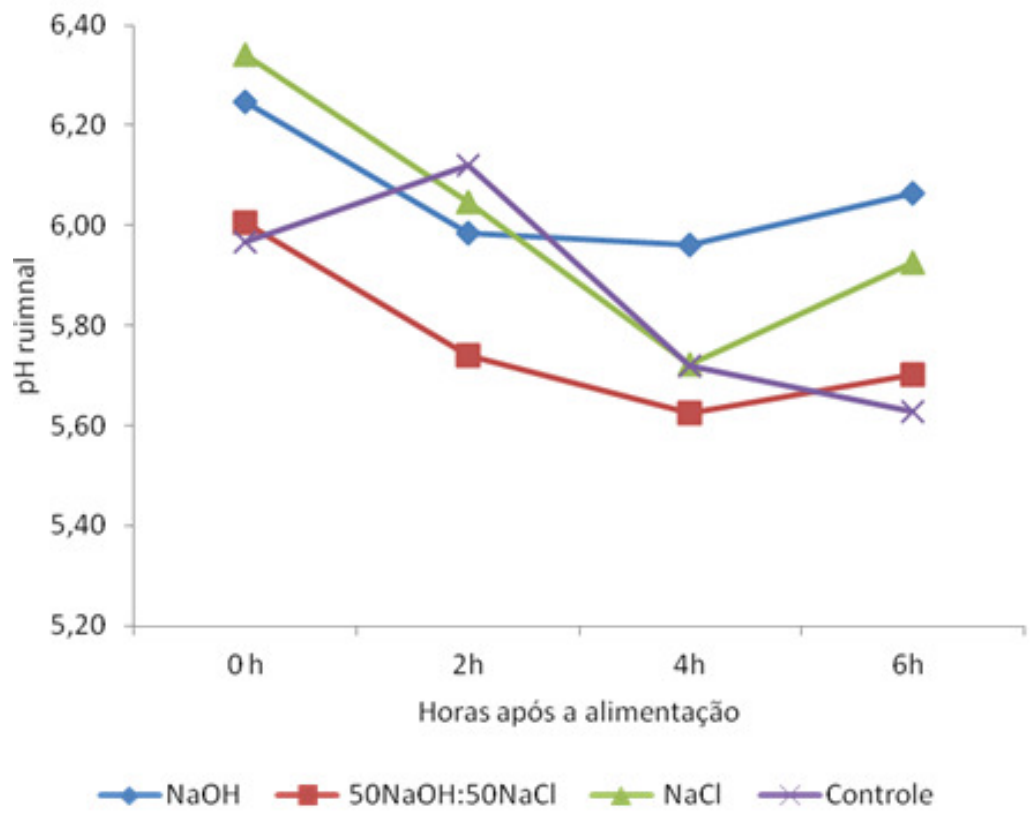

Figura 8: Variação do $\mathrm{pH}$ no fluido ruminal

Para o tratamento com $\mathrm{NaCl}$ observa-se queda mais acentuada nas variações de pH de acordo com os tempos de coleta (Figura 7). López et al. (1994), em dois experimentos avaliando a inclusão de $\mathrm{NaCl}$ sobre os parâmetros ruminais em carneiros fistulados e em ovelhas relataram a queda do $\mathrm{pH}$ devido ao aumento da osmolaridade, sendo no tempo de coleta 3,5 h o que apresentou maior osmolaridade e menor pH. Malafaia et al. (2012), em experimento com adição de níveis crescentes de $\mathrm{NaCl}$ na dieta de bezerras, percebeu que de acordo com o nível de inclusão do $\mathrm{NaCl}$ as bezerras aumentaram o consumo de água, aumentado assim a osmolaridade do líquido ruminal.

A maior concentração de nitrogênio amoniacal $\left(\mathrm{N}^{\left.-\mathrm{NH}_{3}\right)}\right.$ ocorreu nos tratamentos que continham $\mathrm{NaCl}$. Esse aumento pode ser explicado pelo fato do tratamento $\mathrm{NaCl}$ ter possuído tendência de maior consumo de proteína bruta (Tabela 3). Segundo Russel et al. (1992) quanto maior for o incremento e a degradabilidade da proteína da ração no rúmen, maior será a produção de $\mathrm{N}-\mathrm{NH}_{3}$.

Os valores médios $\mathrm{N}-\mathrm{NH}_{3}$ obtidos no presente estudo (Tabela 4) foram superiores ao teor considerado ótimo para concentração de amônia ruminal $(10 \mathrm{mg} / \mathrm{dL})$, conforme ilustrado na Figura 9. Entretanto, a concentração de $\mathrm{N}-\mathrm{NH}_{3}$ pode variar, pois a capacidade das bactérias de sintetizarem proteína e capturar amônia depende da taxa de fermentação de carboidratos (VAN SOEST, 1994). Embora não tenha ocorrido variação na concentração nos diferentes tempos de coleta, a concentração de $\mathrm{N}-\mathrm{NH}_{3}$ nos tempos de coleta 
2 e 4 estão de acordo com a faixa proposta por Mehrez et al. (1977), que relataram a faixa de 19 a $23 \mathrm{mg} \mathrm{N} / \mathrm{dl}$ de $\mathrm{N}-\mathrm{NH}_{3}$ como sendo a máxima atividade fermentativa ruminal.

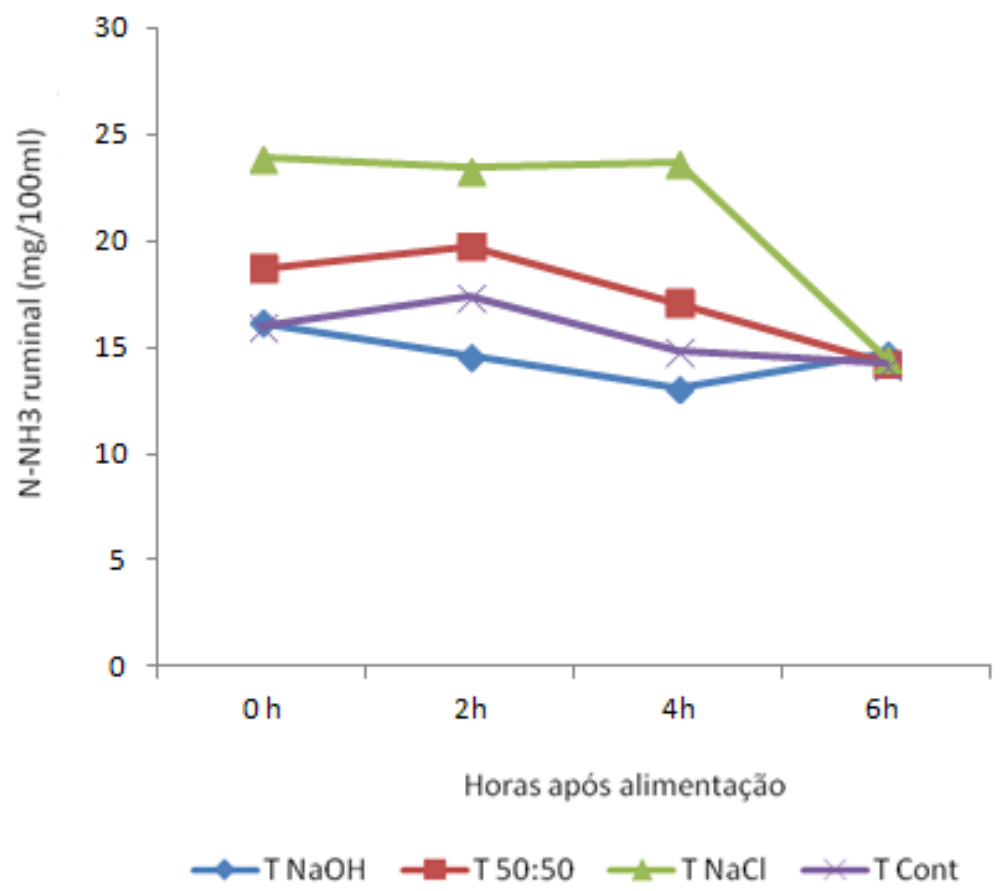

Figura 9: Variação da concentração de $\mathrm{N}-\mathrm{NH}_{3}$ do fluído ruminal

Os valores de glicose plasmática (Tabela 5) não foram influenciados pelos métodos de reconstituição, se mantendo entre os valores de referência de 50 a $80 \mathrm{mg} / \mathrm{dL}$ citados por González e Silva (2006).

Tabela 5. Concentração de glicose no plasma sanguíneo de ovinos de acordo com os tratamentos.

\begin{tabular}{ccccccccc}
\hline & \multicolumn{9}{c}{ Tratamentos } & & & \\
\cline { 2 - 5 } Glicose $(\mathrm{mg} / \mathrm{dL})$ & Controle & $\mathrm{NaOH}$ & $50 \mathrm{NaOH}: 50 \mathrm{NaCl}$ & $\mathrm{NaCl}$ & $\mathrm{P}$ & $\mathrm{CV}(\%)$ & $\mathrm{EPM}$ \\
\cline { 2 - 6 } & 62,0 & 60,0 & 57,0 & 52,30 & 0,4547 & 12,7 & 2,2 \\
\hline
\end{tabular}

Controle: dieta com milho moído sem reconstituição; NaOH: dieta com milho moído e reconstituído com solução alcalina; $50 \mathrm{NaOH}: 50 \mathrm{NaCl}$ : dieta com milho moído e reconstituído com $50 \%$ de solução alcalina $+50 \%$ de solução salina; $\mathrm{NaCl}$ : dieta com milho moído e reconstituído com solução salina; a,b,c - Médias seguidas de letras diferentes nas linhas, são diferentes pelo teste de Tukey com 95\% de confiabilidade; coeficiente de variação(CV); erro padrão da média (EPM).

A glicose é o metabólito que representa a via essencial de energia imediata para os ruminantes, tendo pouco efeito decorrente da dieta, sendo pouco sensível às variações do aporte de energia das rações, uma vez que sua concentração sanguínea é regulada por um 
eficiente mecanismo hormonal: pela insulina, pelo glucagon e com influência do cortisol; destinado a manter constantes as concentrações de glicose (CONTRERAS et al. 2000).

Huntington (1994) cita que os principais substratos para a síntese de glicose são os ácidos orgânicos da fermentação ruminal (principalmente ácido propiônico e ácido láctico), as cadeias de carbono de aminoácidos desaminados e o glicerol proveniente das gorduras. Desta forma, a glicose proveniente da absorção intestinal da degradação do amido, tem essencial função, sendo que ela, teoricamente, apresentara eficiência energética $42 \%$ superior em relação aos ácidos graxos de cadeia curta produzidos pela fermentação no rúmen (OWENS et al. 1986).

Apesar das imagens de micrografia eletrônica permitirem uma avaliação qualitativa dos grânulos, Piovesan et al. (2011) relatam que estudos da microestrutura do amido são de extrema importância para melhor compreender a disponibilização deste carboidrato quando destinado a nutrição animal. As imagens dos grânulos de amido obtidas em microscópio eletrônico de varredura, com aumento de 500x, 600x e 1000 x, estão apresentas na Figura 10.

De acordo com as imagens verifica-se que os tratamentos em que os grãos de milho foram a reconstituídos não apresentaram alterações entre si. Entretanto, foi observada variação em relação ao tratamento controle. Os grânulos de amido apresentaram-se mais espaçados e irregulares, o que provavelmente pode ter ocorrido devido à reidratarão dos grãos triturados, possibilitando novamente o espaço que era ocupado pela água no grão antes de sofrer o processo de secagem.

Observa-se ainda que os grânulos de amido apresentaram variações de tamanhos e, em sua maioria, apresentaram-se de forma arredondada e irregular, com os grânulos de amido possuindo cadeias de projeções em sua superfície, estando assim de acordo com as características citadas por Oates (1997). 

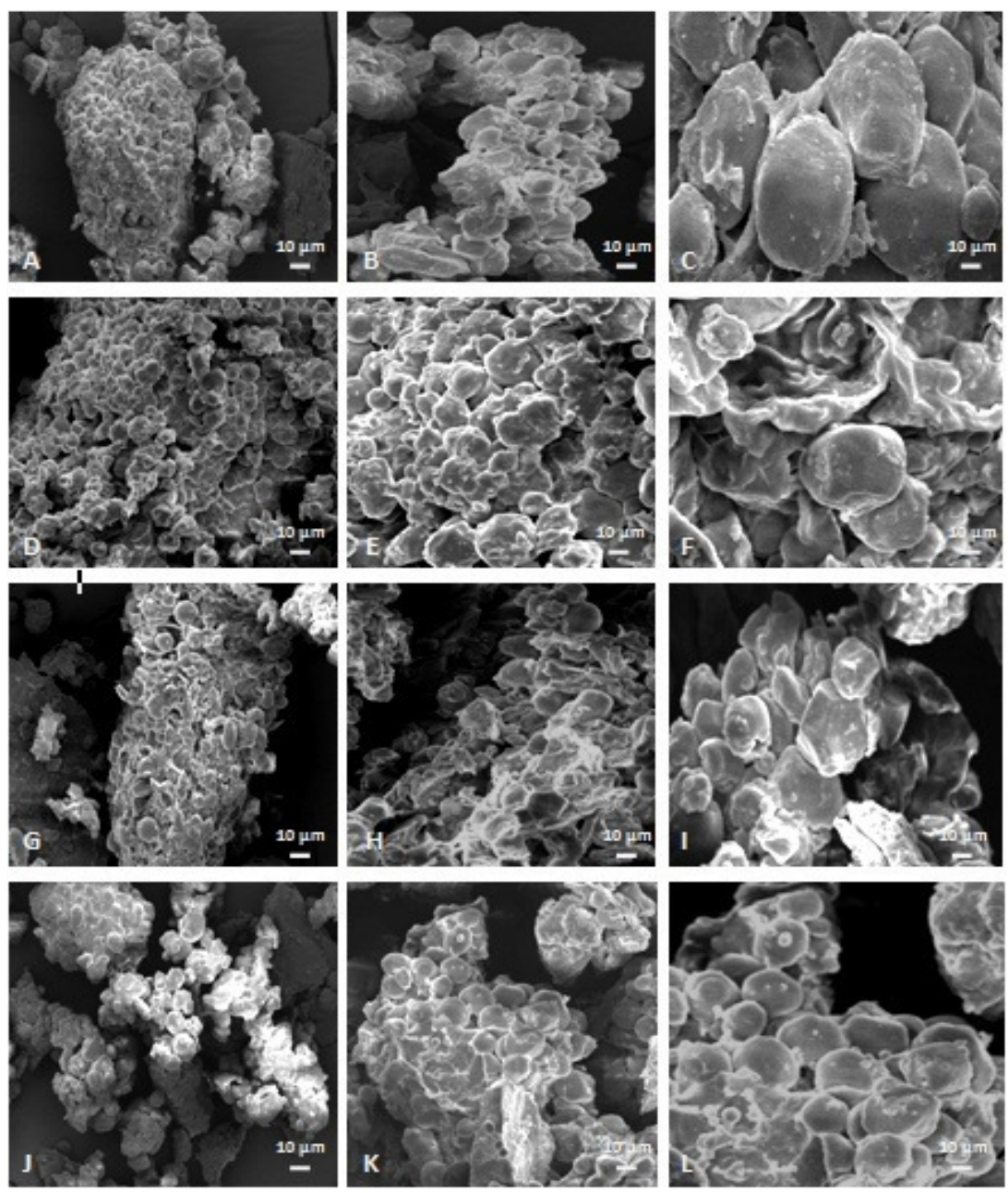

Figura 10 - Fotomicrografia eletrônica do milho reconstituído. A, B e C Controle: milho moído sem reconstituição; $\mathrm{D}, \mathrm{E}$ e $\mathrm{F}-\mathrm{NaOH}$ : milho moído e reconstituído com solução alcalina; G, H e I: $50 \mathrm{NaOH}: 50 \mathrm{NaCl}$ : milho moído e reconstituído com $50 \%$ de solução alcalina $+50 \%$ de solução salina; J, K e L: $\mathrm{NaCl}$ : dieta com milho moído e reconstituído com solução salina.

McNeill et al. (1975) compararam a microscopia eletrônica do grão de sorgo moído seco, reconstituído, floculado e micronizado, e não observaram alteração física nos grânulos de amido entre o sorgo reconstituído e o grão moído seco. Lopez et al. (2002), em pesquisa com microscopia eletrônica de varredura de grânulos de amido de milho destinado para silagem, relataram a importância do rompimento da matriz proteica de grãos para alimentação animal, e constataram que o processo de ensilagem causa apenas pequenas efeitos sobre a matriz proteica. Os autores enfatizam que as alterações citadas não se equiparam ao efeito da temperatura (próximas a $\left.50^{\circ} \mathrm{C}\right)$ ou do calor-umidade $\left(100^{\circ} \mathrm{C} / 16 \mathrm{~h} / 27^{\circ}\right.$ umidade), processos esses mais eficazes para o rompimento da matriz proteica e a superfície do grânulo de amido, o que demanda mais etapas de processo e produção.

Ratnayake e Jackson (2006) avaliaram o comportamento dos grânulos de amido do milho em água (geletanização) em altas temperaturas, relataram que a estrutura do 
amido permaneceu intacta até $50^{\circ} \mathrm{C}$, e que foi observado com auxilio de microscopia de varredura que a estrutura dos grânulos começou a quebrar por volta de $55-60^{\circ} \mathrm{C}$. Segundos esses autores as camadas mais externas dos grânulos tendem a manter a integridade granular durante o aquecimento a $60^{\circ} \mathrm{C}$, porém foi evidenciado que ocorre uma livre circulação interna de polímeros de amido dentro dessa estrutura, e que a partir dos $60^{\circ} \mathrm{C}$ se forma uma solução gelatinosa amorfa constituída da rede de amilopectina e amilose, sendo irreversível o processo a partir $\operatorname{dos} 70^{\circ} \mathrm{C}$. No presente estudo foi observado que o processo de reconstituição causou mudança de temperatura no milho durante o período de descanso de 24 horas, mas neste trabalho a temperatura dentro dos baldes não foi monitorada.

Hoffman et al. (2011) em experimento com milho úmido ensilado (240 dias) observaram por meio de microscopia eletrônica que houve dissociação dos grânulos de amido resultando em grande número de grânulos individuais (maior área superficial) para potencial ataque pelas bactérias ruminais, efeito também causado pela ação da fermentação durante o processo.

Silva (2012) e Silva et al. (2013), utilizando a reconstituição com água antes e após a moagem grosseira $(5 \mathrm{~mm})$ do grão do milho e utilizando solventes (solução alcalina a $0,2 \%$, salina a $5 \%$, e suas combinações com etanol a 70\%) em grãos de milho após moagem grosseira $(5 \mathrm{~mm})$, respectivamente, também não encontram alterações na reconstituição do rompimento da matriz proteica que envolve o grânulo de amido que possam melhorar o acesso da microbiota ruminal ao amido no interior do grânulo. 


\section{CONCLUSÕES}

O efeito da reconstituição dos grãos de milho com as concentrações das soluções utilizadas no presente trabalho não apresentou vantagens em relação ao milho não reconstituído.

Microscopicamente as estruturas dos grânulos de amido não foram afetadas pelos tipos de reconstituição, apenas se observou variação no espaçamento e irregularidade entre os grânulos em relação ao tratamento controle. 


\section{REFERÊNCIASBIBLIOGRÁFICAS}

ARAÚJO, G.G.L.; MOREIRA, J.N.; FERREIRA, M.A.; TURCO, S.H.N.; SOCORRO, E.P. Consumo voluntário e desempenho de ovinos submetidos a dietas contendo diferentes níveis de feno de maniçoba. Revista Ciência Agronômica, v.35, n.1, p. 123-130, 2004.

ASSOCIATION OF OFFICIAL ANALYTICAL CHEMISTS. Official methods of analysis. 15th ed.Washington D. C., 1990. 1141p.

BEAUCHEMIN, K.A.; McALLISTER, T.A.; DONG, Y.; FARR B.I.; CHENG, K.J. Effects of mastication on digestion of whole cereal grains by cattle. Journal of Animal Science, v.72, n.2, p.236-246, 1994.

CHURCH, D.C. Digestive Physiology and Nutrition of Ruminants. Vol. 1 - Digestive hysiology. 3. Ed. Oxford Press Inc. 1979. 350p.

CONTRERAS, P.A.; WITTWER, F.; BÖHMWALD, H. Uso dos Perfis metabólicos no monitoramento nutricional dos ovinos. In: Perfil metabólico em ruminantes: seu uso em nutrição e doenças nutricionais. GONZÁLEZ, F.H.D.; BARCELLOS, J.; PATIÑO, H.O.; RIBEIRO, L.A. (Eds). Porto Alegre: Universidade Federal do Rio Grande do Sul, 2000. 108p.

DETMANN, E.; SOUZA, M.A.; VALADARES FILHO, S.C., QUEIROZ, A.C.; BERCHIELLI, T.T.; SALIBA, E.O.S.; CABRAL, L.S.; PINA, D.S.; LADEIRA, M.M.; AZEVEDO, J.A.G. Métodos para análises de alimentos - Instituto Nacional de Ciência e Tecnologia de Ciência Animal. Visconde do Rio Branco. UFV, 2012. 214p.

DIAS, A.M. Hidróxido de cálcio como aditivo para cana-de-açúcar in natura para alimentação de bovinos. 2009. 88p. Tese (Doutorado em Zootecnia) - Universidade Estadual de Maringá, Maringá, 2009.

EZEQUIEL, J.M.B.; QUEIROZ, M.A.A..; GALATI, R.L.; MENDES, A.R.; PEREIRA, E.M.O.; FATURI, C.; Do NASCIMENTO FILHO, V.F.; FEITOSA, J.V. Processamento da cana-de-açúcar: efeito sobre a digestibilidade, o consumo e a taxa de passagem. Revista Brasileira de Zootecnia, v.34, n.5, p.1704-1710, 2005.

FAHEY, G.C., BERGER, L.L. Los carbohidratos em la nutricion de los rumiantes. In: CHURCH, D.C. El rumiante fisiologia digestiva y nutricion. Zaragoza: Editorial Acribia, c.14, p.305-338, 1993. 
FERREIRA, W.A. Armazenamento de grãos de cereais. In: Manual de armazenamento e embalagem de produtos agropecuários. CEREDA.M. P.; SANCHES, L. (Eds). FEPAF. UNESP. Botucatu. p.96-128, 1983.

GASTALDELLO JR, A.L.; PIRES, A.V.; SUSIN, I.; MENDES, C.Q.; QUEIROZ, M.A.A.; AMARAL, R.C.; GENTIL, R.S.; FERREIRA, E.M.; MOURÃO, G.B.; EASTRIDGE, M.L. Limestone with different particle size and sodium bicarbonate to feedlot lambs fed high grain diets whit or without monensin. Small Ruminant Research, v.114, n.1, p.80$85,2013$.

GONÇALVES, G.D.; Dos SANTOS, G.T., JOBIM, C.C.; DAMASCENO, J.C.; CECATO, U. ; BRANCO, A.F. Determinação do Consumo, Digestibilidade e Frações Protéicas e de Carboidratos do Feno de Tifton 85 em Diferentes Idades de Corte. Revista Brasileira de Zootecnia, v.32, n.4, p.804-813, 2003.

GONZÁLEZ, F.H.D.; SILVA, S.C. Introdução à bioquímica clínica veterinária. Porto Alegre: Gráfica da Universidade Federal do Rio Grande do Sul, 2006, 357p.

HALL, M.B. Determination of Starch, Including Maltooligosaccharides. In: Animal Feeds: Comparison of Methods and a Method Recommended for AOAC Collaborative Study. Journal of AOAC International, v.92, p.42-49. 2008.

HOFFMAN, P.C.; ESSER, N.M.; SHAVER, R.D.; COBLENTZ, W.K.; SCOTT, M.P.; BODNAR, A.L.; SCHMIDT, R.J.; CHARLEY, R.C. Influence of ensiling time and inoculation on alteration of the starch-protein matrix in high-moisture corn. Journal of Dairy Science, Champaign, v.94, n.5, p. 2465-2474, 2011.

HUNTINGTON, G.B. Ruminant starch utilization progresshas been extensive. Feedstuffs, v.66, n.23, p.16-18, p.39-43, 1994.

KARNOVSKY, M.J.A formaldehyde-glutaraldehyde fixative of high osmolality for use in electron microscopy. Journal of Cell Biology. v.27, p.137-138. 1965.

KOTARSKI, S.F.; WANISHA, R.D.; THURN, K.K. Starch hydrolysis by ruminal microflora. Journal of Nutrition, v.122, p178-190, 1992.

LANA, R.P. Sistema Viçosa de formulação de rações. Viçosa: UFV, 2000, 60 p.

LICITRA, G.; HERNANDES, T.M.; VAN SOEST, P.J. Standardizations of procedures for nitrogen fractionation of ruminants feeds. Animal Feed Science and Technology, v.57, p.347-358, 1996.

LOPEZ, A.B.R.C.; LEONEL, M.; CEREDA, M.P.; BERTO, D.A. The Effect of the Ensilage 70 Process of Moist Corn Grains on the Microscopic Characteristics of the Starch. Brazilian Journal of Food and Technology, Botucatu, v.5, n.33, p.177-181, 2002.

LÓPEZ, S.; HOVELL, F.D.D.; MAcLEOD, N.A. Osmotic pressure, water Kinetics and volatile fatty acid absorption in the rúmen of shepp sustained by intragastric infusions. British Journal of Nutrition, New York, v.71, n.2, p.153-168, 1994.

MALAFAIA, P.; LIZIEIRE, R.S.; CRUZ, P.B.; PEIXOTO, P.V. Ethological activities, ruminal parameters and weight gain of calves supplemented with different amounts of sodium chloride. In: Pesquisa Veterinária Brasileira. v.32, n.8, p.803-806, 2012. 
McNEILL, J.W.; POTTER, G.D.; RIGGS, J.K.; ROONEY, L.W. Chemical and Physical Properties of Processed Sorghum Grain Carbohydrates. Journal of Animal Science, v. 40, n.2, p.335-341, 1975.

MEDEIROS, G.R.; CARVALHO, F.F.R.; FERREIRA, M.A.; BATISTA, A.M.V.; ALVES, K.S.; MAIOR JUNIOR, R.J.S.; ALMEIDA, S.C. Efeitos dos níveis de concentrado sobre o desempenho de ovinos Morada Nova em confinamento. Revista Brasileira de Zootecnia, v.36, n.4, p.1162-1171, 2007.

MEHREZ, A.Z.; ØRSKOV, E.R.; McDONALD, I. Rates of rumen fermentation in relation to ammonia concentration. British Journal of Nutrition, v.38, n.3, p.437-443, 1977.

MOE, P.W.; FLATT, W.P.; TYRRELL, H.F. Net energy value of feeds for lactation. Journal of Dairy Science. v.55, p.945-958, 1972.

NATIONAL RESEARCH COUNCIL. Nutrient Requirements of Dairy Cattle. 7 ed. Washington, D.C.: National Academy Press,. 2001. 381p.

NATIONAL RESEARCH COUNCIL. Nutrients requirements of Small Ruminants: sheep, goats, cervids, and new worl camelids. Washington: National Academic Press, 2007. 384p.

OATES, C.G. Towards and understanding of starch granule structure and hydrolysis. Trends in Food Science \& Technology, v.8, p.375-382, 1997.

OLIVEIRA, M.D.S.; QUEIROZ, M.A.A.; CALDEIRÃO, E.; BETT, V.; RIBEIRO, G.M. Efeito da hidrólise com $\mathrm{NaOH}$ sobre a digestibilidade in vitro da matéria seca da cana-deaçúcar (Saccharum officinarum L.). Ars Veterinária, v. 18, n. 2, p.167-173, 2002.

OLIVEIRA, M.D.S.; ANDRADE, A.T.; BARBOSA, J.C; SILVA, T.M.; FERNANDES, A.R.M.; CALDEIRAO, E.; CARABOLANTE, A. Digestibilidade da cana-de-açúcar hidrolisada, in natura e ensilada para bovinos. Ciência Animal Brasileira, v.8, n.1, p.4150, 2007.

ØRSKOV, E.R. Starch digestion and utilization in ruminants. Journal of Animal Science, v.63, p.1624-1633, 1986.

OWENS, F.N.; ZINN, R.A.; KIM, Y.K. Limits to starch digestion in the ruminant small intestine. Journal of Animal Science, Savoy, v. 63, p. 1634-1648, 1986.

PAULIS, J.W.; WALL, J.S. Fractionation and characterization of alcohol-soluble reduced corn endosperm glutelin proteins. Cereal Chemistry, v. 54, p. 1223-1228, 1977.

PINA, D.S.; VALADARES FILHO, S.C.; AZEVEDO, J.A.G.; BARBOSA, A.M.; VALADARES, R.F.D.; DETMAN, E. Efeitos da inclusão e dos tempos de exposição da cana-de-açúcar ao óxido de cálcio sobre os parâmetros digestivos e fisiológicos de novilhas nelores. Revista Brasileira de Zootecnia, v.39, n.7, p.1579-1586, 2010.

PIOVESAN, V.; OLIVEIRA, V.; GEWEHR, C.E. Milhos com diferentes texturas de endosperma e adição de alfa-amilase na dieta de leitões. Santa Maria, Ciência Rural, v.41, n.11, p.2014-2019, 2011. 
PIRES, A.J.V., ROTH, M.T.P., ROTH, A.P.T.P. Inoculantes microbiológicos e aditivos químicos na fermentação e estabilidade aeróbica das silagens de cana-de-açúcar (Saccharum officinarum L.) cru e queimada. In: REUNIÃO ANUAL DA SOCIEDADE BRASILEIRA DE ZOOTECNIA, 41, 2004, Campo Grande. Anais... Campo Grande: SBZ, 2004. CD-ROOM.

PIRES, A.J.V., REIS, R.A., CARVALHO, G.G.P., SIQUEIRA, G.R., BERNARDES, T.F. Bagaço de cana-de-açúcar tratado com hidróxido de sódio. Revista Brasileira de Zootecnia. v.35, n.3, p. 2128-2134, 2006.

QUEIROZ, M.A.A.; SUSIN, I.; PIRES, A.V.; MENDES, C.Q.; GENTIL, R.S.; ALMEIDA, O.C.; AMARAL, R.C.; MOURÃO, G.B. Desempenho de cordeiros e estimativa da digestibilidade do amido de dietas com diferentes fontes protéicas. Pesquisa Agropecuária Brasileira, v.43, n.9, p.1193-1200, 2008.

RABELO, F.H.S.; REZENDE, A.V.; RABELO, C.H.S.; NOGUEIRA, D.A; SILVA, W.A.; VIEIRA, P.F.; SANTOS, W.B. Consumo e desempenho de ovinos alimentados com silagens de cana-de-açúcar tratadas com óxido de cálcio e cloreto de sódio. Arquivo Brasileiro de Medicina Veterinária e Zootecnia, v.65, n.4, p.1158-1164, 2013.

RATNAYAKE, W.S.; JACKSON, D.S. Gelatinization and solubility of corn starch during heating in excess water: new insights. Journal of Agricultural and Food Chemistry, v.17, n.10, p.3712-3716, 2006.

RUSSELL, J.B., O'CONNOR, J.D., FOX, D.G.; VAN SOEST, P.J.; SNIFFEN, C.J. A net carbohydrate and protein system for evaluating cattle diets. I. Ruminal fermentation. Journal of Animal Science, v.70, n.11, p.3551-3561, 1992.

SANDHU, K.S.; KAUR, M.; SINGH, N.; LIM, S. A comparison of native and oxidized normal and waxy corn starches: Physicochemical, thermal, morphological and pasting properties. Food Science and Technology, v.41, p.1000-1010, 2008.

SILVA, J.F.C.; LEÃO, M.I. Fundamentos de nutrição de ruminantes. Piracicaba: Livroceres, 1979. 380p.

SILVA, C.J. Processamento de grãos de milho para uso na alimentação de vacas leiteiras. 2012, 99p. Tese (Doutorado em Zootecnia) - Universidade Federal de Viçosa, Viçosa, 2012.

SILVA, C.J.; Da COSTA, B.F.D.; LEITE, G.G.; MENDES, C.Q. Avaliação das características estruturais e do valor nutricional do grão de milho reconstituídos com diferentes soluções. Revista Eletrônica de Pesquisa Animal, v.1, n.1, p.27-28, 2013.

SNIFFEN, C.J.; O'CONNOR, J.D.; VAN SOEST, P.J. A net carbohydrate and proteinsystem for evaluating cattle diets: II. Carbohydrate end protein availability. Journal of Animal Science, v.70, p. 3562-3577, 1992.

SPIER, F. Efeito dos tratamentos alcalino, ácido e oxidativo nas propriedades de amido de milho. 2010, 72p. Dissertação (Mestrado) - Universidade Federal de Pelotas, Pelotas, 2010 . 
STATISTICAL ANALYSES SYSTEM - SAS. User's guide: statistics. Version 9.2. Cary: 2008.

THEURER, C.B. Grain processing effects on starch utilization by ruminants. Journal of Animal Science. v.63, p.1649-62, 1986.

VALADARES FILHO, J.C.; PINA, D.S. Fermentação ruminal. In: BERCHIELLI, T. T.; PIRES, A.V.; OLIVEIRA, S.G. (Eds.). Nutrição de ruminantes. 1.ed. Jaboticabal: Funep. p.151-182, 2006.

VAN SOEST, P.J. Nutritional ecology of the ruminants. 2.ed. Ithaca:Cornell University, $1994,476 \mathrm{p}$.

VAN SOEST, P.J.; ROBERTSON, J.B.; LEWIS, B.A.; Methods for dietary fiber, neutral fiber, and nonstarch polyssacarides in relation to animal nutrition. Journal of Dairy Science, v.74, p.3583-3597, 1991. 